\title{
THE DOBROGEA WALLS IN THE WRITINGS OF THE POLISH DIPLOMATS ERAZM OTWINOWSKI (1557) AND ANDRZEJ TARANOWSKI (1569)
}

\begin{abstract}
The travelogues of the sixteenth-century Polish diplomats Erazm Otwinowski and Andrzej Taranowski are important, but as yet overlooked sources on the Dobrogea walls as well as on local geography and toponymy. They represent the earliest Western sources for the Dobrogea walls and contain the first pre-modern mention of the forts which are an important feature of these defensive structures. Despite their value, however, these sources have not yet been included in the discussion of the history of the Dobrogea walls. The present paper considers the history of these documents and attempts to place them in the context of the contemporary Polish and German literature. Annotated excerpts from the original Polish and Germans texts together with an English translation will facilitate use of these sources by researchers. They will contribute to our understanding of the history and state of preservation of the Dobrogea walls in a period for which we are otherwise not well informed. Keywords: Dobrogea, linear fortifications, Otwinowski, Taranowski, toponymy
\end{abstract}

\section{Richard A. Mason}

Ukrainian Museum Archive, Cleveland (Ohio), USA medtrans-mason@att.net

DOI: $10.14795 /$ j.v5i1.306

ISSN 2360 - 266X

ISSN-L 2360 - 266X

$\mathbf{I}$

the words of the Romanian historian P. P. Panaitescu (1900-1967),

"Polish travelers, because of their large number and the importance of the reports of their travel, occupy a special place among guests of our countries" ${ }^{\prime \prime}$. This reflects the diplomatic, military and commercial interests of the Polish Commonwealth in maintaining contact with the Ottoman government and the rich trade with the Near East that had historically passed through the Genoese Black Sea colonies and Polish towns such as Cracow and Lwów². The Romanian lands, especially the regions of Moldova and Dobrogea, served as the geographic interface of these contacts.

Study of the careers of Polish diplomats whose official duties necessitated travel through Romanian lands was facilitated by the discovery and publication by Polish scholar Józef Ignacy Kraszewski (1812-1887) in 1860 of a manuscript then belonging to Count Henryk Iliński (17921871) in Romanów (Volhynia) ${ }^{3}$. This manuscript contained, among other

PANAITESCU 1930, 3: "Călătorii poloni, prin numărul lor mare şi prin importanţa relaţiilor lor de călătorie, ocupă un loc aparte între acești oaspeți ai țărilor noastre” While including Otwinowski, Panaitescu omits without any comment Taranowski's report, or even any mention of him in his collection.

2 PANAITESCU 1933; DZIUBIŃSKI 1965; DZIUBIŃSKI 1996; MINKOVA 2014.

3 KRASZEWSKI 1860, 41-61; TARDY/VÁSÁRY 1974, 218-219. 
miscellaneous materials dating through the reign of Sigismund III Vasa (d. 1632), the Polish texts of three travelogues by Polish diplomats of the final decade of the long reign of Sigismund II Augustus (1520-1572; ruled 1530-1572), namely Erazm Otwinowski (1557), Andrzej Taranowski (1569) and Piotr Zborowski (1568). Kraszewski recognized the value, in particular, of the three travelogues, calling them "compelling materials for the future historian of our relations with the Turks" .

The manuscript discovered and published by Kraszewski is believed to be the seventeenth-eighteenth century manuscript now preserved in the Jagiellonian Library (Cracow, Poland) under Signature 52675, having been donated to that institution by Count Iliński's sonin-law, Henryk Stecki, in November $1893^{6}$. Kraszewski published the three travelogues in his Podróze i poselstwa polskie do Turcyi (Polish Travels and Embassies to Turkey) and they were again studied in the late nineteenth century by the Croatian scholar Petar Matković (1830-1898) in his Putovanja po balkanskom poluotoku XVI. vieka (Travels in the Balkan Peninsula in the Sixteenth Century; 1891). The texts of Otwinowski and Taranowski are uniform in their graphic presentation in the surviving manuscript, there being no significant differences between them ${ }^{7}$.

Although primarily of interest for the information they provide on Ottoman and Russian military and social history in the late sixteenth century, two of the three travelogues contained in Kraszewski's collection include interesting mentions of the linear fortifications encountered in the Dobrogea on their respective authors' journey to the Ottoman capital. These mentions have not yet been included in the discussion of the history of the Dobrogea walls. The objective of the present paper is to place these sources in their historical context and to explore implications for future research.

\section{ERAZM OTWINOWSKI, WYPISANIE DROGI TURECKIEJ (1557)}

Erazm Otwinowski was born in Liśnik Duży (Lublin voivodeship) in or around $1528^{8}$. One of twelve children of an impoverished noble family, limited material status and lack of a comprehensive formal education did not prevent him from living at the courts of influential noblemen, ultimately entering the service of Stanisław Tęczyński, then voivode of Kraków, in 1554. With Tęczyński's support, he joined Andrzej Bzicki's mission to Constantinople (the year is uncertain, but is dated to 1551-1557). He seems to have travelled with Tęczyński's son, Jan Baptysta, in western Europe (1555-1559), as well as on a mission to the Swedish King, Eric XIV, in Stockholm in November $1561^{9}$. He also accompanied the young Tęczyński in September 1563 on a 4 KRASZEWSKI 1860, 5: "Sa to szacowne materyaty dla przyszłego historyka stosunków naszych $z$ Turcya."

5 INWENTARZ 1938, 370-371, "Collectanea Historica"; POLLAK 1966, 183-184; TARDY/VÁSÁRY 1974, 218.

6 INWENTARZ 1938, 371.

POLLAK 1966, 203. Pollak describes the manuscript as being bound in half-calf, in a good state of preservation. For a full table of contents of Jagiellonian MS. 5267 see INWENTARZ 1938, 370-371.

8 WILCZEK 1994, 15-16 for discussion of year of Otwinowski's birth.

KOT 1934, 7; BARYCZ 1979, 106; WILCZEK 1994, 18-19 questions the 1561 mission. surreptitious voyage to marry Princess Cecilia Vasa, falling briefly into Danish captivity ${ }^{10}$. He then married and retired to his ancestral estate in Liśnik Duży. In the interregnum following the death of Sigismund II Augustus, Otwinowski backed various contenders for the Polish throne, ultimately supporting the successful candidate, István Báthory ${ }^{11}$. As early as his time with the Tęczyńskis, Otwinowski became involved in Calvinism, switching allegiance to the antiTrinitarians after taking part in the 1563 Cracow synod of the 'Arian' faction of the Calvinist community. As a convinced Unitarian acclaimed for living by its principles, Otwinowski moved to Raków (Świętokrzyskie Voivodeship, the recently founded center of the "Polish Brethren") before 1598, becoming an influential figure in shaping the sect's publishing policies ${ }^{12}$. He died in June 1614, probably in Raków. Otwinowski's works include a variety of political and religious polemical works impugning the lapses and corruption of the king and nobility, with a more nuanced treatment of issues such as Islam and gender equality than was typical in his age. His works indicate a good command of Latin, possibly also of German ${ }^{13}$. To him have also been attributed, though probably erroneously, a series of erotic poems ${ }^{14}$

The full title of Otwinowski's travelogue in the Cracow manuscript (Wypisanie drogi tureckiej, gdym tam z posłem wielkim wielmożnym panem Andrzejem Bzickim, kasztelanem chetmskim, od króla Zygmunta Augusta posłanym roku pańskiego 1557 jeździt, "Description of the journey to Turkey when I went there with Lord Andrzej Bzicki, Castelan of Chełm, sent by King Sigismund August A.D. 1557"), added in a later hand, led Kraszewski to date Otwinowski's visit to Constantinople to that year ${ }^{15}$. Spuler accepts this date without comment but places another embassy by the same Bzicki in $1551^{16}$. Because it is generally believed that Otwinowski had been travelling in western Europe with the young Tęczyński between 1555 and 1559, some scholars have rejected the date in the Cracow manuscript, arguing instead for a later date, such as $1566-1569$, based on textual evidence that points to the early years of Selim $\mathrm{II}^{17}$. Other scholars, such as the late nineteenth-century Polish orientalist, I. Janicki, have even questioned the attribution of this text to Erazm Otwinowski ${ }^{18}$. The text of the Wypisanie drogi tureckiej does, however, specify that its author did take part in Andrzej Bzicki's mission, which historians 10 WILCZEK, 1994, 18 (citing J. B. Tęczyński’s biographer, K. Gutaker source not available); WILCZEK 2016, 104-105.

11 WILCZEK 2016, 105-106.

2 WILCZEK 2016, 46

WILCZEK 1994, 18-19.

WILCZEK 1994, 27-34; WILCZEK 2016, 106 disputes this attribution.

KRASZEWSKI 1860, 6: "W rękopiśmie który mamy przed sobą, na górze nad tytułem, ręka późniejsza nieco dopisała, że dyaryusz jest dziełem Otwinowskiego, imienia nie wymieniono."

16 SPULER 1936, 390-391.

PREJS 1999, 28, 56-61. Cf. KRASZEWSKI 1860, 12: "tam też jest drugi most przez odnoge morska, ale mniejszy, od dzisiejszego Selima cesarza zbudowany," referring to the stunning, still extant bridge at Küçükçekmece southwest of Istanbul. WILCZEK 1994, 25 recreates a chronology of Otwinowski's life, citing other events that do place Otwinowski in Poland during the period between 1556 and 1560; in fact, WILCZEK 1994, 19 tends to question some aspects of Otwinowski's reported travels with the young Tęczyński during this period.

18 JANICKI 1879, v (n. 1), who argues from genealogical and heraldic grounds against this attribution. 
Wypisanie drogi tureckiej, ed. Kraszewski (1860), p. 10:

Ultima Julii. Ruszyliśmy się od Dunaja, nocleg mila za Babą w lesie, w tem miasteczku Babie jest bałwochwalstwo u grobu Mikołajowego, dirbiszowie albo mniszy tureccy.

\section{Augusti. Nocleg we wsi Tangribredy mil 6.}

2. Nocleg we wsi Alaczapi, pod małym Bazarczykiem, gdzie mura są od morza Czarnego do morza Białego od Anastazyusa cesarza zbudowane, dla częstych utarczek Tatarów i Bułgarów do Grecyi, których jeszcze ruiny stoją mil 6.

generally date to $1557^{19}$; Andrzej Bzicki died in $1567^{20}$. Two of Otwinowski's biographers, Kot and Barycz, suggest that Otwinowski wrote the Wypisanie only later in his long life, from memory, supplemented, perhaps, by notes taken by himself or by friends who had visited Constantinople on other, later occasions, perhaps even after $1596^{21}$.

The Wypisanie represents one of the earliest Polish descriptions of Ottoman customs, state structure, education, and curiosities. Ottoman society and culture are presented in a fairly objective and sympathetic manner. Otwinowski, who later wrote on gender equality, was intrigued by the possibilities for social advancement in Ottoman society, especially for the originally Christian children who had been given in tribute to the Ottomans or captured during wars and were trained at the imperial court. Otwinowski's own personal religious evolution was not without significance in shaping his interest in Islam, especially in the context of his progression toward Unitarianism, whose adherents were attacked for their allegedly pro-Muslim sympathies ${ }^{22}$.

Za Babq - Babadag (445' 53" N, 28 44' 31" E; Turkish Babadağ, "Baba's Mountain"), municipality of Tulcea county. Its name derives from the thirteenth-century dervish, Sari Saltuk Baba, who is said to have settled in this area with a number of Turcomans. It is said that the Baba Saltuk mentioned by the Moroccan traveller Ibn Battuta (1304-1369) as a place he visited in 1332 refers to the Babadag in the Dobrogea but seems more likely to be a place in the

\footnotetext{
19 POCIECHA 1937, 185-6; KOT 1934, 3-5.

20 POLLAK 1966, 185. A possible clue to dating the embassy is Otwinowski's mention of "[nocleg] 13 we wtorek 13 7bris, ipso die Exaltationis S. Crucis Romanae," i.e. "the $13^{\text {th }}$ [night rest] on Tuesday, 13 September, the same day as the Exaltation of the Holy Roman Cross". 13 September fell on a Tuesday in 1558 but the feast of the Holy Cross in the Roman calendar falls on 14 September, which was, in fact, a Tuesday in 1557. Otwinowski, despite being a Protestant, was very aware of Catholic practices; this was also an important feast for the Orthodox and fell on the same day in the Julian Calendar. It is possible that the "13" (rather than "14") was carried over in error from the beginning of the line with its unusual construction. This would seem to confirm a date of 1557 for the embassy.

${ }^{21}$ KOT 1934, 4; BARYCZ 1979, 641-645. The passage discussed in the present paper may provide an example of confusion of details, as the author conflates the Dobrogea walls with the Thracian Long Walls of Anastasius (KRASZEWSKI 1860, 11). This issue and its implications is discussed in greater depth below.

22 NOSOWSKI 1974, 139; GRÓDZ 2015, 448; ZARĘBSKI 2015. The Turczyn ("Turk") of Mikołaj Rej, a contemporary Polish Calvinist poet whose arguments spared Otwinowski from trial on charges of sacrilege for desecration of the Eucharist in Lublin in 1564, is an example of a more positive view of the Turks.
}

31 July. We moved from the Danube, overnighting a mile behind Babadag in the woods, in the town Baba there is idolatry at the tomb of Nicholas, [performed by] dervishes or Turkish monks.

1 August. Night rest in the village of Tangribredy, six miles.

2 [August]. Night rest in the village of Alakap, near Little Bazarczyk, where are the walls built by the Emperor Anastasius from the Black Sea to the White Sea, against the frequent attacks of the Tatars and Bulgarians againt Greece, the ruins of which still stand for six miles.

Crimea near the fortress of Sudak ${ }^{23}$. The town was conquered by Bayezid I in his 1393 Danubian campaign. Baba, which Otwinowski uses as the name of the town and declines as a regular feminine noun, derives from the honorific baba used by the Bektaşi order, either as the head of a lodge (tekke) or more generally as a respected spiritual guide or leader. The mila, or mile, is not the Roman mile of 1000 double paces (ca. $1569 \mathrm{~m}$ ) but based instead on the "German" mile, or league, which, with variations amongst the Polish regions, ranged from $6250 \mathrm{~m}$ (short mile) to $7810 \mathrm{~m}$ (long mile) ${ }^{24}$. Thus, Otwinowski's daily stage was about $37-45 \mathrm{~km}$, a typical day's travel on a post road (Taranowski, who followed the same route, says his party "rode the post"25).

U grobu Mikołajowego - Süleyman I visited the tomb (türbe) and lodge of Sar1 Saltık in Babadag in 1538. The former structure survives as the Mausoleul Sari Saltuk Baba in Babadag. In his Greek word list, the Ottoman geographer Evliyâ Çelebi (1611-1682) gives Sarı Saltık as the Turkish equivalent of İsveti Nikola (VIII.256b), who is revered as a Christian saint of Slavic origins by the Greek and Slavic inhabitants of the Balkans; when he discusses Christian saints or holy days, he usually mentions Sarı Saltık and İsveti Nikola conjointly ${ }^{26}$. Evliya Çelebi made three visits to Dobrogea and was interested in Sarı Saltık, the most influential derviş-ğazi in the Islamization of the Balkans ${ }^{27}$. Otwinowski's own interest in the Bektaşis is evidenced by his further mention of their "idolatry" (batwochwalstwo) in Babaeski, a town in Turkish Thrace through which he passed, his remark at that place in the manuscript alluding to the present passage ${ }^{28}$.

Dirbiszowie albo mniszy tureccy - Babadag was (re)founded by Bayezit I in 1389. Bayezid's foundation at Babadag included a mosque, an imaret (soup kitchen), a medrese (college), a bath and türbe (monument) to Sarı Saltık. In all probability the Bektaşi dervishes were associated with the cult from the first; by these or their successors Sar1 Saltık was brought into the cycle of Hadji Bektaş ${ }^{29}$.

\footnotetext{
23 HASLUCK 1912, 206.

STAMM 1938, 32-38. JACOBY 1965, 116 found a range of 5,400 to 8,390 meters for a sample of 200 maps dated 1448-1638. KURAT 1966, 029 estimates Taranowski's "mile" at $10 \mathrm{~km}$.

25 KRASZEWSKI 1860, 41: "puściliśmy się naprzód na podwodzie".

26 ANETSHOFER 2012, 297; BACCI/ROHDE 2014, lxxx.

HASLUCK 1912, 203-206; ANETSHOFER 2012, 296

28 KRASZEWSKI 1860, 11: "Tam też jest takie drugie batwochwalstwo, jako $i$ w Babie; pierwszy nocleg od Dunaju."

29 HASLUCK 1912, 205-206.
} 
Tangribredy - Matković connects Otwinowski's

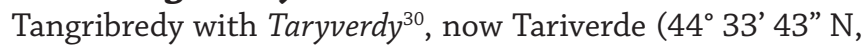
$\left.28^{\circ} 36^{\prime} 11^{\prime \prime} \mathrm{E}\right)$, a village of Cogealac commune, Constanţa county. The secretary's version of the report of Jan Gniński, Polish ambassador to the Porte in 1677-1678, mentions a Staserverde, described as a "Tatar village" reached in two days from Babadag ${ }^{31}$. Taranowski, who followed the same route, has Hordmerdy (K, Holoferdt $N$, Harowerdj $W$, Horowerdy $B$ ), in which Tardy and Vásáry see a corrupted Hudaverdi ${ }^{32}$, which has gained a certain acceptance ${ }^{33}$. For further discussion, see corresponding note to Taranowski's report, below. Tariverde was the site of a German settlement from the 1870's onward, the alternate (German) name of which was Dorothea. The evidence for this toponym prior to that time is limited to Evliyâ Çelebi's seventeenth-century Seyahatnâme, which mentions Tanriverdi at two places in lists of toponyms ${ }^{34}$. This is closer to Otwinowski's spelling. Otwinowski gives a distance of six (German) miles, or approximately $37-45 \mathrm{~km}$, which is approximately the measured road distance today.

Alaczapi - Poarta Albă $\left(44^{\circ} 13^{\prime} 00^{\prime \prime} \mathrm{N} 28^{\circ} 24^{\prime} 00^{\prime \prime} \mathrm{E}\right.$; "white gate"), a communein Constanţa County, was previously known as Alakapî. Taner 2011, 21 derives the toponym from Crimean Tatar/Crimean Turk. alakapî ("arcade”). Alternately, Turk. adjective ala ("mottled, spotted") occurs frequently as a prefix in toponyms; the Turk. kapî ("gate") corresponds well with the Romanian place name Poarta Albă. Together with Taranowski's mention in 1569, this represents one of the earliest attestations of the name Alakap. The significance of Otwinowski's alternate spelling, i.e. Alaczapi, is not clear.

Małym Bazarczykiem - The identification of Otwinowski's "Little Bazarczyk" is unclear, Alakap being described as being "beneath" it. The name does not appear to be otherwise attested. Matković identifies "Little Bazarczyk" with Megidia ( $\left.44^{\circ} 15^{\prime} 1^{\prime \prime} \mathrm{N} 28^{\circ} 15^{\prime} 41^{\prime \prime} \mathrm{E}\right)$, the old Karasu, which was reported as a Tatar settlement as early as $1555^{35}$. If it is, in fact, Karasu or Megidia, this might be of significance for our discussion as both walls extend westward from Alakap in the direction of the Karasu lakes. While it is unlikely that Otwinowski had the time or inclinication to follow them in that direction, he may have learned of their course from his informant. Taranowski also mentions a "little town (miasteczka) Bazarczyk" immediately after describing the walls at Alakap, implying it to be next destination but without indicating a specific proximity ${ }^{36}$. This Bazarczyk has been identified with the Bulgarian town of Bobrič (now Tolbuhin), whose Turkish name was Pazarcik or Haci Oğlu Pazarcik ${ }^{37}$. Otwinowski has wielki Bazarczyk ("Great Bazarczyk") as the resting place after two days' travel. The latter would appear identical with Taranowski's Bazarczyk.

Gdzie mura sq - Alakap lies just east of the chain of lakes and marshes occupying the Karasu valley leading toward the Danube. Here, two of the three Dobrogea

\footnotetext{
30 MATKOVIĆ 1891, 184.

31 PUŁASKI 1907, 21; PANAITESCU 1930, 79.

32 TARDY/VÁSÁRY 1974, 248.

33 HOLOD/HALENKO 2014, 372.

34 EVLIYÂ ÇELEBI 1984, 83, 191.

35 MATKOVIĆ 1891, 159, 184

36 KRASZEWSKI 1860, 42: “Ztamtąd do miasteczka Bazarczyka.” Taranowski

tends to mention only more important, populated places.

37 MATKOVIĆ 1891, 159-160; TARDY/VÁSÁRY 1974, 248.
}

walls, namely the Large Earthwork Wall and the Stone Wall, approach from the southeast: they converge west of Alakap and follow the southern rim of the Karasu valley. Otwinowski conflate the Dobrogea walls, which he describes with reasonable accuracy, with the Thracian Long Walls (tÕ makrÕn tercoj, Murus Anastasii) whose construction, or at least repair, in the late fifth to early sixth century is attributed to Anastasius (d. 518) ${ }^{38}$. A possible source is the first book of Marcin Bielski's Kronika wszytkiego świata, which discusses these walls ${ }^{39}$. Bielski correctly locates the walls at Silivri. He gives their remaining length here as six miles, a distance he seems to use more with the meaning of a "day's travel" of around $40 \mathrm{~km}$. Taranowski describes the walls at Alakap in greater detail (see below).

Morza Czarnego - The northern terminus of the Long Wall on the coast of the Black Sea is near the Turkish village of Evcik, west of the Terkos Lakes in the eastern Thracian peninsula.

Morza Białego - The "White Sea," Turkish Akdeniz, is the counterpart to the Black Sea, Turkish Karadeniz. Although referring strictly to the Mediterranean, it may be taken to include its appurtenances, such as the Aegean and Sea of Marmara. The Marmara end of the Long Walls is at Silivri, ancient Selymbria, which Otwinowski visited on his way to Constantinople but he does not mention them. Taranowski, who took a different route, must have encountered the walls between Vize (Wisze) and Çatalca, but does not explicitly mention them ${ }^{40}$. This use of "White Sea" is unusual in Polish. The learned Bielski errs when he uses Hellespont for the Sea of Marmara, which Otwinowski correctly calls the Propontis ${ }^{41}$. The only occurrence of White Sea in Bielski is a passage describing the Bosphorus ${ }^{42}$ - a passage taken from Taranowski's report ${ }^{43}$. Interestingly, Otwinowski's "Black Sea to White Sea" corresponds with Taranowski's word order, while Bielski has the opposite, i.e. "White Sea to Black Sea." It is also possible that, whatever his source, Otwinowski had a local, perhaps, Turkish informant.

Dla częstych utarczek Tatarów i Butgarów do Grecyi - This is, of course, an anachronism for the Anastasian Walls (and the Dobrogea Walls), the Tatars and Bulgars having not yet become a threat to the Eastern Roman Empire. While the Bulgars were (later) a perennial enemy of the Byzantines and no longer a menace in Otwinowski's time, the Tatars, if not reflecting a "generic" foe for the Greeks, were certainly a major factor on Poland's southeastern frontiers. Archaeological research over the last decades has unanimously confirmed the late dating of the Dobrogea walls: their assignment to the Roman period no longer finds supporters. Therefore, any remaning debate

\footnotetext{
WHITBY 1985

39 BIELSKI 1856, 1.20: "I dla tegoż Anastazyus cesarz uczynił był długi mur od Silibryej, który nad samem morzem helespontskiem leży, aż do czarnego morza, chcac mieć pokój przed nimi w Konstantynopolu."

40 Taranowski mentions some walls near Vize which the Turks were demolishing but these seem not to be identical with the Anastasian Long Wall: "Około którego [zamka] byli cztery mury, każdy na trzy sążenie wzmiąsz, ale skoro go Turcy dostali, tedy te mury zburzyli” (KRASZEWSKI 1860, 42).

${ }^{41}$ KRASZEWSKI 1860, 11. In the same passage, Otwinowski mentions the White Sea in geographical context.

42 BIELSKI 1856, 2.1175. This, of course, is found only in the postumous 1597 edition.

43 KRASZEWSKI 1860, 43.
} 
on the political power that built these fortifications is now limited to whether the walls are the work of the Byzantines or must be ascribed to the First Bulgarian Tsarate ${ }^{44}$.

\section{ANDRZEJ TARANOWSKI, KRÓTKIE WYPISANIE DROGI Z POLSKI DO KONSTANTYNOPOLA (1569)}

A report much different in scope and of greater interest in terms of its bearing on the Dobrogea walls, is the Krótkie wypisanie drogi z Polski do Konstantynopola ("Short Description of the Route from Poland to Constantinople") of the Polish diplomat, Andrzej Taranowski, who travelled from Lublin to Constantinople in 1569 as ambassador of the Polish king to the Ottoman Sultan Selim II. Beside valuable information on Ottoman and Russian military history in the late sixteenth century, Taranowski's report also contains an interesting mention of the linear fortifications he encountered in the Dobrogea on his journey to the Ottoman capital.

Andrzej Taranowski has been lauded as one of the outstanding diplomats of the sixteenth century and was a high officer of the Polish crown. Relatively little is known about his early years. His descent is traced from a noble Galician family ( $z$ herbu Belina) of the Przemyśl region (Little Poland), which had contributed a series of bishops and court officers since the mid-fifteenth century ${ }^{45}$. The Polish Jesuit Kasper Niesiecki (1682-1744) describes him as being "modest in height and learning but great in heart, negotiating ability and activity" ${ }^{46}$. Taranowski began his diplomatic career leading three embassies to Denmark and one to Sweden before $1569^{47}$. His great contributions lay in the East, however, being repeatedly sent as ambassador to the Porte by Sigismund II Augustus (1569-1570, 1572), and, later, by Stefan Báthory $(1574-1575,1579)$, who also sent him to the Crimean Tatar khanate $(1577,1578)^{48}$. This was a time of rising tensions in Eastern Europe, as Poland under Sigismund was at war with Muscovy, then ruled by Ivan IV (the Terrible). This conflict, particularly in the context of the Ottoman-Polish treaty, renewed in 1568 after the succession of Selim II, colored Polish diplomacy in the East at a time when Poland was initially considered a possible ally by both the Ottomans and by the Crimean khanate, then ruled by Devlet Giray ${ }^{49}$. During the interregnum after Sigismund's death in 1572, Taranowski visited Moscow in the face of Ivan IV's threatening posture toward Lithuania. He also participated in his capacity as Lord Treasurer (wielkiej komornik) and Cupbearer for Galicia (podczaszy halicki) in the process leading to Stefan Báthory's election as king of Poland. Under Stefan Báthory, Taranowski led at least one further embassy to the Crimean Tatars, being held captive by them through 1578, and was received by Murat III, who had succeeded Selim in $1574^{50}$. The date of his death is uncertain,

\footnotetext{
44 MASON/CROITORU 2016, 362.

45 NIESIECKI 1743, 4.303-304; NIESIECKI 1842, 5-9.

46 MATKOVIĆ 1891, 176; TURYN 1929, 14, both citing Niesiecki (citations see n. 51: "miernego wzrostu i nauki, ale serca, obrotu i dzielnosci wielkiej").

47 BIELSKI 1856, 1173.

48 SPULER 1936, 391-394.

49 SPULER 1936, 384-385; KOŁODZIEJCZYK 2011, 99

50 SPULER 1936, 393-394; JABLONOWSKI 1937, 30.
}

being placed at the end of the sixteenth century ${ }^{51}$.

The immediate background of Taranowski's embassy of 1569 was rooted in the military situation in the East that dominated the last years of Sigismund II Augustus' long reign $^{52}$. In May 1569, Selim II had sent a message to the Polish king, requesting permission for a Turkish army of 30,000 men to cross Polish territory in a campaign against Muscovy. The request was carried by a Polish nobleman, Joachim Strasz (?-1571), a colorful character in his own right: as a child he had been captured by the Tatars and, having been sold as a slave to the Turks, had converted to Islam under the name of Ibrahim Bey. Sigismund, then pre-occupied with the historic Lublin Sejm of that year, rejected the request, being unwilling to risk a new war with Muscovy, but felt obliged to express his friendship toward the sultan by means of an embassy led by his trusted courtier ${ }^{53}$. According to the account in the posthumous 1597 edition of Marcin Bielski's Kronika Polska (derived from a version of Taranowski's account distinct from $K$ ), Taranowski started from Lublin on "the vigil of Corpus Christi ${ }^{54}$," i.e. 8 June, 1569 (O.S. = 29 May N.S.), reaching Constantinople on 14 July. He returned to Warsaw on Christmas Eve (24 December 1569) ${ }^{55}$.

Taranowski's report, likely written shortly after his return to Poland, is known from several sources. It first appeared in print in a German translation ( $N$ ) published in Nuremberg by Dietrich Gerlatz (sic) in 1571, just two years after the completion of the mission, under the title Beschreybunge einer Reyse oder eins zuges, eins fürnemlichen Polnischen Herrn, von Königklicher Polnichen wirden Botschafftweiß gen Constantinopel, vnd dannen inn die Tartarey gezogen: Mit bericht vnd meldunge mancherley seltzamer hendel, vnd grossen Schaden, so die Türcken dazumal erlitten, sehr nützlisch vnnd wolzulesen (Description of a Journey, or, the Travels of a noble Polish gentleman on an embassy from the Polish King to Constantinople and thence proceeding into Tartary; with a relation and reports, quite useful and worth reading, of certain strange transactions and injuries suffered by the Turks) ${ }^{56}$. The Polish bibliographer, Karol Józef Estreicher (1827-1908), first editor of the Bibliografia Polska, not knowing of the existance of the Vienna manuscript, initially ascribed $N$ to Martin Broniovius, whose Tartariae Descriptio, printed in Cologne in 1595, was well known. His son, Stanisław (1869-1939), who assumed control over the project in 1908, corrected this attribution. A very similar contemporary German translation (W), which Tardy and Vásáry propose to have been the basis for the Nuremberg edition, was discovered in 1958 in the Wiener Haus-, Hofund Staatsarchiv (Turcica I, fasc. 25, Konv. 1569 Oct.-Dec. ff. 97r-118r) by the Russian-born Tatar-Turkish historian Ades Kurat (1903-1971) $)^{57}$.

\footnotetext{
NIESIECKI 1743, 4.303-304; NIESIECKI 1842, 6.

2 TARDY/VÁSÁRY 1974, 213-216.

BIELSKI (1856), 1173: “Z czym poslal do niego Dworzanina swego Andrzeja Taranowskiego Herbu Bylina”.

${ }^{5}$ BIELSKI (1856), 1173: “Ten tedy wyjechawszy $z$ Lublina $w$ wigilię bożego ciała tegoż roku...” MATKOVIĆ 1891, 179.

55 MATKOVIĆ 1891, 172-179; TARDY/VÁSÁRY 1974, 217.

56 ESTREICHER 1936, 26. The 1571 edition is mentioned under a slightly different title in Meusel's update of Struve and Buder's Bibliotheca Historica, II.1.250 (Leipzig, 1783).

7 KURAT 1966, 39-40; TARDY/VÁSÁRY 1974, 220; HOLOD/HALENKO $2014,353$.
} 
Estreicher gave precedence to $N$, but it is very likely, as already proposed by Matković, that the German text is a translation, albeit amplified in places, of a Polish original. With the exception of occasional interpolations, it has been remarked that both German texts "slavishly" follow the extant Polish text. Here, it is believed that $N$ was prepared on the basis of $W$, whose compiler had immediate access to the Polish text ${ }^{58}$. $N$ contains numerous errors and faulty readings in the transcription of place and personal names. The editor of $N$ has consistently applied the rules of German orthography, while $W$ often corresponds more closely to Polish spelling, indicating that the manuscript is at least one step closer to Taranowski's lost original text. It is also more likely that the text reached Nuremberg by way of Vienna. At that time, the Polish and Austrian courts maintained good mutual relations that kept them informed of developments with common enemies. Thus, it would be likely that Taranowski's report made its way to Vienna, where it was immediately translated into German ${ }^{59}$.

A Polish text $(K)$, preserved in the Cracow manuscript described above, was published by J. I. Kraszewski in $1860^{60}$. The Polish text begins immediately with Taranowski's report, lacking the foreword found in the German versions. A further manuscript containing Taranowski's report was the so-called Lelewel copy $(L)$. Dated to 1813, the manuscript was first attested in the Muzeum Narodowy im. Swidzińskich in Sulgustów and later in the Krasinski Library (Signature $718)^{61}$. The Krasiński Library was ultimately incorporated into the Biblioteka Narodowa at Warsaw and was known to Estreicher ${ }^{62}$. As nearly all former Krasiński manuscripts were destroyed in 1944, Taranowski's report in Polish survives in a single manuscript. $L$ is considered to have been copied from $K^{63}$, but, due to its destruction, its exact position cannot be determined. The manuscript contained only Taranowski's report ${ }^{64}$, suggesting a distinct provenance that bypassed $K$. Turyn, writing in 1929 and thus able to consult the manuscript, states that it was taken from Bielski (see below) ${ }^{65}$.

A corresponding text, adapted and abridged, and transposed from the first to third person, appears also in the posthumous 1597 Cracow edition of Marcin Bielski's Kronika Polska, prepared by the historian's son, Joachim, and is prefaced with a very brief account of the antecedents of Taranowski's embassy and a few remarks about his diplomatic career ${ }^{66}$. Estreicher suggested that Bielski's text was derived from a Polish printed original, distinct from $K$,

\footnotetext{
58 TARDY/VÁSÁRY $1974,220$.

59 MATKOVIĆ 1891, 173-174; TARDY/VÁSÁRY 1974, 220.

60 KRASZEWSKI 1860, 41-61; TARDY/VÁSÁRY 1974, 218-219.

61 Pułaski 1915, 751 (19 leaves); POLLAK 1966, 203. Pollak does not give

a signature; TARDY/VÁSÁRY 1974, 218 erroneously give " 118 " as the signature. ESTREICHER 1936, 26 confirms “718”.

62 ESTREICHER 1936, 26.

63 TARDY/VÁSÁRY 1974, 218

64 PUŁASKI 1915, 751-752: “718. (3547). J. Lelewel. Jędrzeja Tarnowskiego [sic!] droga do Carogrodu 1569. | K. 1. Jędrzeja Tarnowskiego droga do Carogrodu i Astrahanu 1569. J. Lelewel, Warszawa 1813.”

65 TURYN 1929, 16: "Subscriptio Lelewelii in extremo folio docet libellum ex Chronicis BIELSKIi descriptum esse." As discussed below, it is likely that Lelewel transcribed the text from F. Bohomolec's 1764 Warsaw edition.

66 BIELSKI 1856, 1173-1174; for the edition, see ESTREICHER 1894, 88. The pagination in the 1597 edition is 626-638.
}

now lost ${ }^{67}$

Finally, a family of Russian manuscripts preserve extended sections of Taranowski's text, but these concern the campaign against Astrakhan and do not touch on the portion of Taranowski's report describing his outward journey to Constantinople ${ }^{68}$.

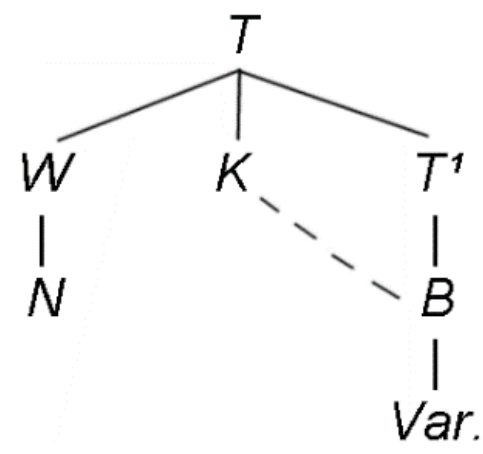
represents Taranowski's original (1569?), now lost; $\mathrm{T}^{1}$ is Estreicher's hypothetical Polish printed version (now lost), from which was derived the passage $(B)$ in Joachim Bielski's 1597 edition of his father's Var. Kronika Polska, together with subsequent derivatives (Var. $)^{69}$.

$K$ is the text in the Iliński manuscript (now in Cracow) as published by Kraszewski (1860). $W$ is the Viennese manuscript first published by Tardy and Vásáry (1974), from which these authors suggest that $N$, the 1571 Nuremberg edition, was derived. The position of the Lelewel copy $(L)$ is not clear but is considered an early nineteenth century copy of $K . K$ is believed to be the closest to Taranowski's original text $(T)$, closer than all other versions, including the two German versions ${ }^{70}$.

In the German text of $W$ and $N$, we replace ŭ with ü, $\int$ with s. Passages that exist only in the German variants but not in the Polish text are enclosed in $\langle>$. The commentary treats primarily the Polish text of $K$, supplemented by $B$. Except for the German words and phrases in $W$ and $N$ that have no counterparts in either $K$ or $B$, no additional commentary is provided to the texts of $W$ and $N$. The reader is directed to the corresponding places in the commentary to the Polish text.

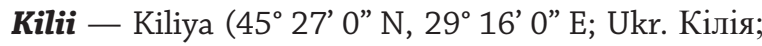

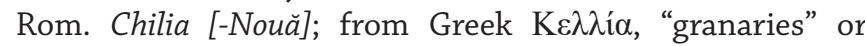
tÕ Kell...on 1/2toi tÕ LukostÒmioa, "wolf's mouth"71), municipality of Odesa oblast, seat of Kiliya Rayon of southwestern Ukraine. It was a major Moldavian port, founded by Stephen the Great of Moldavia in order to counteract the Turks, who, in the fifteenth century, had taken control of Chilia Veche, an earlier settlement on the right bank of the Danube. It was conquered by the Ottomans in 1484. Taranowski considered Kilia his point of entry into Turkish territory, this being a Turkish custom house $\left(\right.$ gümrük) ${ }^{72}$.

Wyzine - Diminutive of wyz, the European sturgeon or beluga (Huso huso, whence German Hausen) is a species of anadromous fish in the sturgeon family (Acipenseriformes). It is found primarily in the Caspian and Black Sea basins. The sturgeon has historically been an economically important

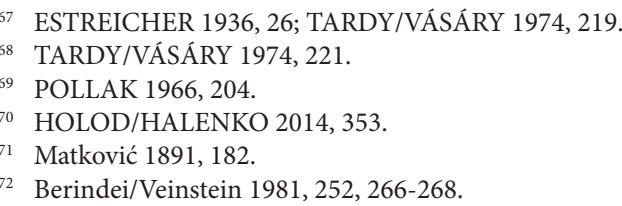




\section{K = Polish text of 1569}

\section{Krótkie wypisanie drogi z Polski do Konstantynopola, ed. Kraszewski (1860), pp. 41-42:}

Z Kilii jechałem galarem wzgórę wody rzeki Dunaja do jaza, kędy wyzinę łowią, który leży ćwierć dnia jazdy od Kilii, z Kilii do Tulczy miasteczka, z Tulczy do Baby, z Baby puściliśmy się naprzód na podwodzie do wsi Hordmerdy. Ztamtąd do miasteczka Hałakapy, a wtem tam koło tego miasteczka są jeszcze mury i wały zburzone, kędy się Grekowie bronili poganom, kędy mury i przekop od morza aż do Dunaja uczynili, |42| którego muru i przekopu było mil trzydzieści wzdłuz. Tenże mur stoi jeszcze zburzony, i miejsca są znaczne, kędy się Grekowie obozem okopywali, ale od wielkości pogańskiej są starci i zbici. Ztamtąd do miasteczka Bazarczyka.
From Kilia I sailed in a scow up the water of the Danube River to an embankment, where they were catching sturgeon, which lies a quarter of a day's journey from Kilia, from Kilia to Tulcea; from Tulcea to Babadag; from Babadag we went ahead with the postal carriage to the village of Hordmerdy. Then to the town of Alakap: there are walls and ramparts there, where the Greeks defended against the heathen, and the walls and the ditches stretching from the sea to the Danube, $|\mathbf{4 2}|$ whose wall and ditch was thirty miles long. This wall stands still though demolished, and the places are considerable, where the Greeks camped, but from the pagan strength are smitten and shattered. From here to the town of Bazarczyk.

\section{B = Text in Bielski's Revised Kronika Polska $(1597)^{73}$}

\section{(ed. J. Bielski, 1597, p. 626)}

Z Kiliey iechał wzgorę rzeki Dunaia do Jazu, kędy wyzinę łowią, który Iaz leży cztery dni jazdy od Kiliej. Z Iazu do Tulce miasteczka. Z Tulce do Baby. Z Baby puścił się na podwodzie do wsi Horowerdy. Stamtąd do miasteczka Halapapy, a tam u tego miasteczka ieszcze sa wały y mury zburzone, kędy się Grekowie kiedyś bronili naszym ludziom: idzie ten mur y wal na 30 mil wzdłuż. Stamtąd do miasteczka Bazarczyka, ... (ed. Bohomolec, 1764, p. 570)

Z Kilii iechał wzgórę rzeki Dunaia do Iazu, kędy wyzinę łowią: który Iaz leży cztery dni iazdy od Kilii, z Iazu do Tulce miasteczka, z Tulce do Baby, z Baby puścił się na podwodzie do wsi Horowerdy. Z tamtąd do miasteczka Halapapy; a tam u tego miasteczka ieszcze są wały y mury zburzone, kędy się Grekowie kiedyś bronili naszym ludziom; idzie ten mur y wal na 30 mil wzdłuż. Z tamtąd do miasteczka Bazarczyka, ...

(trans. from Turowski, 1856)

From Kilia, he ascended the river Danube to Jaz, where they catch sturgeon, which Jaz lies four days' journey from Kilia; from Jaz to the little town of Tulcea; from Tulcea to Baba; from Baba he travelled with the post carriage to the village Horowerdy. Then to the little town Hala|1174|papa; there are still in that town destroyed ramparts and walls, which the Greeks defended against our people; that wall and rampart extend for 30 miles. Then to the little town of Bazarczyk, ... species in the Danube delta ${ }^{74}$.

Do jazy - $B$ gives $J a z$ as the place at which Taranowski landed (jechat wzgórę rzeki Dunaja do Jazu), this being a misunderstanding of "jechałem galarem wzgórę wody rzeki Dunaja do jaza" in K. Polish jaz is a "dam" or "sluice"75, but can also mean "weir"76, many of which were set up along the Danube to trap the migratory sturgeon, as Taranowski mentions. $B$ also reads cztery dni jazdy (four days' travel) for ćwierć dnia jazdy (a quarter-day's travel) in $K$.

Jechatem galarem - The type of watercraft Taranowski's party used is not clear, the text calling the boat a galar (jechatem galarem). Here, there is a possible discrepancy between the Polish and German texts. $W$ (and by extension, $N$ ) translates the original Polish galar as Gallee( $n$ ) in German. The latter, usually with the meaning "galley," normally suggests a sea-going vessel. Sea-going ships could

${ }_{73}$ BIELSKI 1856, 1173-1174: Z Kiliej, jechał wzgórę rzeki Dunaja do Jazu, kędy wyzinę łowią, który Jaz leży cztery dni jazdy od Kiliej; z Jazu do Tulcze miasteczka, z Tulcze do Baby, z Baby puścił się na podwodzie do wsi Horowerdy. Ztamtąd do miasteczka Hala-|1174|papy; a tam u tego miasteczka jeszcze są wały i mury zburzone, kędy się Grekowie kiedyś bronili naszym ludziom; idzie ten mur i wal na 30 mil wzdłuż. Ztamtąd do miasteczka Bazarczyka,

74 BELDICEANU/BELDICEANU-STEINHERR 1975, 41-43.

75 TARDY/VÁSÁRY 1974, 247; MATKOVIĆ 1891, 180.

${ }^{76}$ MAYENOWA 1975, 315. reach Galaţi and even Brăila, most of them ascending by way of the Chilia branch ${ }^{77}$, but the word was also used for riverine craft. The Polish galar, however, is closer to the scow, a broad-beamed, flat-bottomed boat suitable for rivers Galar: galera, statek rzeczny bez masztu; eine Galeere, bei uns ein Flußschiff ohne Mast. ${ }^{78}$.

Tulczy - Tulcea lies on the right bank of the Danube near the western, upstream end of the delta region of the Danube, $7 \mathrm{~km}$ from the branching of the Kilia and Tulcea arms. At the site of Tulcea, the ancient Aegyssus, the Tulcea branch enters a bend and narrows, explaining its suitability as a site for crossing the river and controlling riverine navigation. Tulcea came under Turkish control after Mehmet I reconquered the Dobrogea in $1417^{79}$.

Baby - Babadag; see commentary to Otwinowski's report, above.

Puściliśmy się naprzód na podwodzie - Taranowski specifies (in the Polish text) that a wagon or carriage (podwód; Turkish koçu, araba ${ }^{80}$ ) was used. There is a mention of the use of wagons (koçu) provided by the voivode of Moldavia

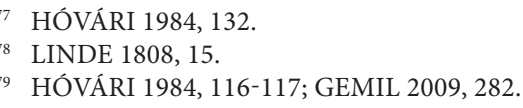


to an Ottoman envoy sent to Poland in 1576-157781. The Polish expressions jechać na podwodzie or za podwode jechać were used in contemporary sources to translate the Latin cursu publico a vehiculis publicis ire/uti ${ }^{82}$, exactly Taranowski's meaning here. The German versions simply say that the party "rode the Post" (seindt wir die Post geritten), as the postal service provided in most places in the Holy Roman Empire by the Thurn and Taxis organization (including Nuremberg) used stage coaches rather than horses.

Hordmerdy - Otwinowski has Tangribredy, for which see commentary to his report, above. Taranowski has Hordmerdy (K, Holoferdt $N$, Harowerdj $W$, Horowerdy B), in which Tardy and Vásáry see a corrupted Hudaverdi ${ }^{83}$. They do not comment on this derivation; it is presumably Turkish, e.g. hüda, an honorific = "divine" and verde, "rose". Kurat, following $W$, reads Haroverdi, again without comment ${ }^{84}$. Interestingly, $W$ and $N$ both calls this a "Greek" village, which may challenge a derivation of the toponym from Turkish or Tatar. Matković identified the corresponding place in Otwinowski's account with Taryverdy, modern Tariverde (see above $)^{85}$, whose distance from Babadag Otwinowski gives as six (German) miles ( $45 \mathrm{~km}$ ). This corresponds approximately with the modern road distance along DN-22. Yerasimos identified the place with the former Karamurat, now Mihail Kogălniceanu in Constanţa County, a place mentioned by Evliyâ Çelebii ${ }^{86}$, but its distance from Babadag is nearly double that to Tariverde and it would have been impossible to reach from Babadag in a single day.

Hałakapy - Alakap, now Poarta Albă $\left(44^{\circ} 13^{\prime} 00^{\prime \prime} \mathrm{N}\right.$ $28^{\circ} 24^{\prime} 00^{\prime} \mathrm{E}$; "white gate"), a commune in Constanţa County; see commentary to Otwinowski's report, above. The variant readings (Hala kapi $W$, Halakupi $N$, Halapapy $B$ ) are simple orthographic errors. Marcin Paszkowski, who included an excerpt from $B$ in his Polish translation of Guagnini's Sarmatiae Europeae descriptio (1611), gives Hala Pasza (< Turk. *Halapaşa). Together with Otwinowski's mention in 1557 , this represents one of the earliest attestations of the name.

Sa jeszcze mury i waty zburzone - Alakap lies just east of the chain of lakes and marshes that occupy the Karasu valley leading toward the Danube. Here, two of the three Dobrogea walls, namely the Large Earthwork Wall and the Stone Wall, approach from the southeast: they converge west of Alakap and then follow the southern rim of the Karasu valley. The Small Earthwork Wall would be encountered further to the south. Coming from the north, the Polish travelers encountered at Alakap an area with a high concentration of remaining traces, there being in addition to the walls of their associated forts at least two free-standing fortifications guarding this terrain east of the natural barrier of the Karasu lakes.

Kędy się Grekowie bronili poganom - As Otwinowski before him, Taranowski attributes the fortifications to "the Greeks," i.e. the Byzantines. The more intellectual Otwinowski, although he conflates the Dobrogea

\footnotetext{
81 FAROQHI 1982, 532.

82 MAYENOWA 1998, 104

83 TARDY/VÁSÁRY 1974, 248

84 KURAT 1966, 029.

85 MATKOVIĆ $1891,180,184$

86 YERASIMOS 1991, 284
}

and Thracian Long Walls, identifies the heathen against whom the walls were erected, as the Bulgars and Tatars. As Holod and Halenko note in this regard, "the landscapes of Ottoman Rumelia attracted Taranowski's attention first and foremost through buildings that serve as proof that these lands had belonged earlier to the Greeks/Byzantines" Interestingly, $B$, which Estreicher believed to have been derived from a now-lost Polish printed version distinct from $K$, has "our people" (naszym ludziom) in place of "the heathen" (poganom). While ludzi, "(a group of) people" (like the German Leute) is frequent in Bielski, the present expression, with the meaning of "people of our nationality = Poles", is unusual in this part of the work, the only other occurrence being in the description of a military situation against the Germans $^{88}$. As Taranowski had not yet written his account at the time of Marcin Bielski's own last edition, this passage was added by Joachim Bielski, editor of the posthumous 1597 edition and may reflect his personal style. However, Marcin Bielski uses the expression frequently in the early part of the Kronika with the even broader meaning of Slavs or speakers of Slavic languages ${ }^{89}$. In the sixteenth century, the Polish aristocratic and intellectual classes derived their descent from the Sarmatians, whose incursions in the Danube lands were written about by ancient authors as well as by Polish historians. For example, Bielski cites the earlier historian Maciej Miechowita, who spisat też obie Sarmacye, europejskq i skityjskq, to jest, o nas $i$ Tatarach piszqc ("he also described both Sarmatias, the European and the Scythian, writing, that is, about us and the Tatars") ${ }^{90}$.

Kędy mury i przekop od morza aż do Dunaja uczynili - Both Otwinowski and Taranowski recognize the defensive purpose of the walls to obstruct the route passing between the Danube and the sea.

Którego muru i przekopu - It is interesting that Taranowski, having spoken of "walls and ramparts" in the plural (mury $i$ waty) above, here speaks of "the wall and the ditch" in the singular. It is possible that the "walls and ramparts" refer to the many defensive structures around Alakap, much as he speaks of the walls around Vize ${ }^{91}$, while the "wall and the ditch" refer to the linear fortifications proper with their wall and ditch. Otwinowski refers to the "walls" in the plural. Both Moltke and Vincke in the early 1840s note the double and triple walls; Jules Michel in the 1850s noted that it appeared to be common knowledge amongst the Turks that there were three distinct walls, giving also their respective Turkish names ${ }^{92}$.

Mil trzydzieści wzdłuz - Otwinowski gives the length of the walls as six miles, which, as discussed above, is estimated at $37-45 \mathrm{~km}$. This distance seems to represent, for that writer, about a "day's travel" or about $40 \mathrm{~km}$. Taranowski by contrast gives the length of the walls at thirty miles, which, if we assume that his mile corresponds to the
7 HOLOD/HALENKO 2014, 356.
88 BIELSKI 1856, 2.767.
89 For example, BIELSKI 1856, 1.21: “Także jako Mezyę wielką opanowawszy Bulgarowie przezwali ja Bulgarya od swego imienia, tedy też i Mezya mniejsza nazwa na jest Serbia od Serbów albo Sorabów, też ludzi naszych."
90 BIELSKI 1856, 1025. Maciej Miechowita's Tractatus de duabus Sarmatis (1517) was an early source for the "Sarmatism" that would become fashionable in Poland.
91 KRASZEWSKI 1860, 42.
92 Michel 1862, 230-231. Michel discusses the region of Alakap at pp. 248-249. 


\section{W = Viennese Manuscript (1569?)}

Kurtze beschreibung des wegs gegen Constantinopel aus pollen, ed. Tardy, Vásáry (1974), p. 226:

| 97r | ... auß der Statt Kilia bin ich die Thonwasser auf in ainer Galleen biß zu dem grossen Fach da man die hausen fenget, welches ain viertl tagraiß von Kilia ligt, gefahren.

Von Kilia in ain Stattlin mit nam(m)en Tulza, von Tulz in ain statt Baby.

Von Baby seindt wir die Post geritten, in ain $<$ Griechisch $>$ dorff Harowerdj.

| $97 \mathbf{v}$ | Von dannen in ein Stettlin, Hala kapi bey demselbigen Stättlin seindt noch allte mauren vnnd Gräben, da sich die Griechen der haiden gewehrt haben, vnnd alda ainen graben vnnd Mawr, <bey zwo clafftern dickh von dem mehr, wa es der Thonaw am nechst(en) ist, > in die Thonaw gemacht, welche mauren dreissig meillen lang sein, welche noch zum thail auff den heuttigen Tag gesehen word(en).
| 97r | ... from the city Kilia I sailed up the Danube water in a galley as far as the large weir, where they were catching sturgeon, which lie a quarter day's journey from Kilia.

From Kilia to a town with the name Tulcea, from Tulcea to a city Babadag.

From Babadag we rode the post to a $<$ Greek $>$ village, Harowerdj.

|97 v| From there to a town, Alakap; by the same town there are still old walls and ditches, where the Greeks defended against the heathen; < and here is a ditch and a wall, about two fathoms thick, from the sea, where it is nearest the Danube,> built to the Danube, which walls are thirty miles long, which in part still can be seen to the present day.

\section{$\mathbf{N}=$ Nuremberg edition (1571)}

Beschreybunge einer Reyse oder eins Zuges eins fürnemlichen Polnischen Herrn von Königlicher Polnischen wirden, Botschafftweiß gen Constantinopel, ed. Gerlach (1571), p. 1

|1r| ... auß der Stadt Kylia bin ich die Tainwasser hinauf, in einer Galleen biß zum grossen Bach da man den gefaren. Von Kylia inn ein Stedtlein mit namen Tulza, von danen inn ein Stadt Babi, seind wir die Post geritten inn ein $<$ Griechisch > Dorff Holoferdt.

Von dannen in ein Stedtlein Halakupi, bei den selben Stedtein seind noch alte mauren und greben, da sich die Griechen der Heiden gewehret haben, unnd allda einen graben und mauren <bey zwei klafftern dick, von dem Meere wo der Tain am nechsten ist,> unnd sich inn die 30. meylwegs erstreckt, gemacht, wie denn solchs auff den heutigan tag noch zusehen. Hausen fengt, welches ein viertel tagreiß von Kylia liegt,

$|\mathbf{1 r}|$... from the city of Kylia I sailed up the water of the Danube in a galley as far as a large creek where they were catching sturgeon, which lies a quarter of a day's journey from Kilia. From Kilia to a town with the name Tulcea, from there to a city Babadag, we rode the post to a <Greek> village 'Holoferdt'.

From there to a town Alakap; by the same town there are still old walls and ditches, where the Greeks defended against the heathen and even there a ditch and walls about two fathoms thick; from the sea, where the Danube is at its nearest, they extend out up to 30 miles away, as can be seen up to the present day.

Bazarczyka - This Bazarczyk is identified with the

"German" mile, or league, would give a excessive length of 187.5 to $234.3 \mathrm{~km}$, much longer than the distance between the Danube and the Black Sea at this place. If, however, we take Taranowski's mile as the mila włoska (“Italian", i.e. Roman mile) of $1569 \mathrm{~m}$, this would give a distance of about $47 \mathrm{~km}$, which agrees much more closely with Otwinowski's figure. This reported length also squares well with the actual distance from the Black Sea to the Karasu lakes, as both Taranowski and Otwinowski seem to refer to the length of the surviving remains rather than the total distance between the Black Sea and the Danube.

Kędy się Grekowie obozem okopywali - The Polish obóz refers to a camp, especially a military encampment ${ }^{93}$. There are several forts and fortlets belonging to both the Large Earthwork Wall and the Stone Wall, which converge west of Alakap as they reach the Karasu lakes. This appears to be the only pre-modern reference to the forts that are so significant a feature of the Dobrogea walls. This passage is absent from $B$ as well as from both German texts.

\footnotetext{
93 MAYENOWA 1990, 310-314
}

arian town of Bobrič (now Tolbuhin), whose Turkish

Ain 〈Griechisch> dorff Harowerdj - The characterization of this place as a "Greek" village is lacking in the extant Polish versions. As noted above, this may challenge, or at least add a new aspect to, the derivation of this toponym from a Turkish or Tatar original.

Ainen graben vnnd Mawr - $W$, "a ditch and a wall"; in $N$, however, einen graben und mauren, "a ditch and walls". Because Taranowski wrote above of "walls" but here mentions "a ditch and a wall", it is possible that the editor of $N$ attempted in this way to correct what he perceived to be an error in his Vorlage. See commentary to corresponding passage in the Polish text above for further discussion.

Bey zwo clafftern dickh - This statement is lacking in the extant Polish versions. Both $W$ and $N$ give the diameter of the wall at two fathoms. The Klafter, like the fathom, represents the span of a man's outstretched arms. The name was Pazarcik or Haci Oğlu Pazarcik ${ }^{94}$.

\footnotetext{
94 MATKOVIĆ 1891, 159-160; TARDY/VÁSÁRY 1974, 248.
} 
corresponding Polish unit is the sq̨żen, consisting of six feet, and ranging from 1.758 to 1.7865 meters ${ }^{95}$. The measurement must be considered an estimate, as the formulation bey zwo clafftern, "about two fathoms," would suggest. It is also likely that Taranowski is considering only the embankment, not the total breadth of the embankment plus the ditch(es) when making this estimate. At about 4 meters, this generally corresponds with historical measurements of some surviving segments the walls, especially those by Carl Schuchhardt in 1885, 1898 and 1917, and Grigore Tocilescu in the $1890 s^{96}$. These measurements, taken in the era prior to the mechanization of agriculture in socialist Romania, would be considered much closer to conditions in Taranowski's time, although anthropogenic damage especially to the Stone Wall started quite early, its stone core being quarried for building materials.

Von dem mehr, wa es der Thonaw am nechst(en) ist - This statement is lacking the extant Polish versions. The remark underscores what Taranowski perceived as the military importance of the walls, running from the Danube to the Black Sea. It shows also that Taranowski (or the translator of $W$, if this is an interpolation) possessed a reasonably clear understanding of the geography of the Dobrogea and was able to draw geographical conclusions regarding the placement of the walls.

\section{DISCUSSION}

The reports of Erazm Otwinowski (1557) and Andrzej Taranowski (1569) represent two of the earliest mentions in Western sources of the linear earthwork fortifications of the Dobrogea. They also provide what appear to be the only two mentions of the Dobrogea walls in the surviving Polish literature of the period. The third travelogue in the manuscript published by Kraszewski, that of Piotr Zborowski $(1568)^{97}$, does not provide details on his route but an extant letter shows Zborowski visited Adrianople ${ }^{98}$ and may thus have followed the same route to Constantinople. Later Polish travelers, whose works have been collected by P. P. Panaitescu ${ }^{99}$ and recently examined by $C$. Croitoru with regard to data relative to ancient linear fortifications in Romania ${ }^{100}$, refer to walls north of the Danube, in the Siret-Prut interfluve, Bessarabia or elsewhere in Romania, but say nothing of the Dobrogea walls. A late source, the letters of Kajetan (or Jan) Chrzanowski (1780), discuss the topography of the Karasu valley at length but do not mention the walls ${ }^{101}$.

One reason for later authors' silence on the Dobrogea walls probably relates to a change in routes followed by the embassies, many of which seem to have crossed the Danube further west or south, as at Brăila, rather than following the Sağ Kol ("right-hand road") route ordinarily used in the sixteenth century ${ }^{102}$. This underscores the value of the 95 STAMM 1938, 31.

96 For the literature, see Schuchhardt 1918, 4; Mason/Croitoru 2016, 240. For a description of the Dobrogea walls in the region of Alakap, see especially Schuchhardt 1918, 23-26 (= Mason/Croitoru 2016, 270-275).

97 KRASZEWSKI 1860, 65-81.

98 YERASIMOS 1991, 280.

99 PANAITESCU 1930.

100 CROITORU 2007, 57-69.

101 PANAITESCU 1930, 224-243. Panaitescu gives his initial as $W$., while the sources waver between Kajetan and Jan.

${ }_{102}$ DZIUBIŃSKI 1965, 240. Examples include Wojciech Miaśkowski present testimonies for a period in the walls' history for which we are otherwise not well informed. To date, however, these sources have not been included in the historical discussion of the Dobrogea walls. The purpose of the present study was to examine the relevant passages in these two documents with respect to their implications for further research.

While the walls, as military objects of impressive size, certainly attracted both men's attention, this interest should be viewed also in the broader context of a landscape that was certainly alien from, yet, in many ways, associated with the lands they knew. As Holod and Halenko remark with respect to Taranowski (but which would apply equally to Otwinowski), "such selectivity in perceiving the surrounding landscape was clearly filtered through his awareness of the conflict between the Polish and Ottoman realms, which in turn represented the confrontation between the two religions, Christianity and Islam. ... Historic memory, then, aided in turning the nameless ruins into symbols of lost Christian rule; even the walls of Trajan and the memory of the Roman Empire's pre-Christian past counted. The ruins were perceived and represented as markers of a territory that, in his audience, had belonged to the Christian world, and thus needed to be regained"103.

The route followed by Otwinowski and Taranowski through the Dobrogea represents the so-called "Turkish Road" of the sources ${ }^{104}$. It corresponds with the so-called Sag Kol that began at Kirkkilisse (modern Kirklareli in Turkish Thrace) and extended north toward the Danube delta ${ }^{105}$. With northern termini at Danube landing places such as Tulcea or Isaccea, this was the main commercial artery connecting the Ottoman capital with its northeastern territories, along which the Levantine produce, such as silk, cotton and spices were exchanged for slaves, horses, cattle and sheep from the northern shore of the Black Sea ${ }^{106}$. This route was based on a foundation of Roman roads having a nidus at Aegyssus (modern Tulcea) and extending southwards from the Danube, first by way of the series of Western Pontic cities that had been founded by the Greeks, later branching out inland toward Alakap and Tropaeum Traiani ${ }^{107}$. In what is now Turkish Thrace, south of the Istranca mountains, three routes led to Constantinople: a northerly, coastal route; a middle route that leads eastward from Kirklareli through Vize and Çatalca (which Taranowski followed); and a southerly route, which Otwinowski followed from Kirlareli south to Adrianople and then eastwards by Havsa, Babaeski and Çorlu to Silivri (which he misremembers as Silistrya), where the route of Egnatian Way was joined ${ }^{108}$. While neither Otwinowski nor Taranowski provide abundant comments on their passage through Dobrogea, the two reports compliment one another and allow good reconstruction of the route that

(1640), Ieronim Radziejowski (1667), Rafał Leszczyński (1700), Stanisław Chomętowski (1712) and others. See Panaitescu 1930 for these sources.

103 HOLOD/HALENKO 2014, 356. Here, the authors, no doubt based on the conventional literature, make a connection that Taranowski himself did not make: both Taranowski and Otwinowski to consider the walls a product of the "Greeks", that is, either the late Eastern Roman Empire or the Byzantines. 104 HÓVÁRI 1984, 117.

105 HEYWOOD 1977, 40-41; Yerasimos 1991, 56-57. The route of the Sa ̆ Kol was essentially unchanged between the sixteenth and eighteenth centuries.

106 HÓVÁRI $117,1984$.

107 MILLER 1916, 507-508.

108 MILLER 1916, 513-514. 
these envoys followed in the mid-sixteenth century.

Otwinowski reached Turkish territory at a place he calls Obkurzyc under the date of 29 July $^{109}$ but Oblinczyc at the time of his return journey on 30 September ${ }^{110}$. The variant spellings may reflect erroneous readings by the seventeenthor eighteenth-century scribe who copied Jagiellonian MS. 5267: Ob-ku/lin-r/c-zyc. This has been identified with Isakköy (modern Isaccea) ${ }^{111}$, which Otwinowski describes as a Turkish customs house ${ }^{112}$ where they were obliged to remain one day. This was a convenient crossing point, in particular, for those travelling from the Prut valley. Taranowski crossed the Danube further downstream, having embarked at Kilia, then connecting with the land routes at Tulcea. From there, both parties followed the same route, apparently halting at the same places. This may have been dictated by the fact that they both appear to have used the Turkish postal system with its elaborate network of relay stations (menzilhane) along what was one of the main arteries in Turkey's European domains. Typically, relay stations were established at intervals of six to twelve hours' riding, or at about 20 to $70 \mathrm{~km}$, depending on terrain $^{113}$.

Although both documents purport to be reports of diplomatic missions, their respective nature and purpose differ in several important aspects. First, their authors: Taranowski was a grandee of Poland, holder of high offices and the king's legate, while Otwinowski, although a nobleman, was a minor one who visited Turkey in the entourage of a greater lord. We know from surviving diplomatic documentation that reports of embassies customarily consisted of two distinct documents, namely, the report of the ambassador himself, which highlighted the purpose and achievements of the mission, an "executive summary" of sorts; followed by a report by a "secretary", which dealt with more mundane details, such as the itinerary and other bits of "intelligence" that might interest officials in the royal chancery. Taranowski's report better fits the model of the ambassadorial report, while Otwinowski's report, regardless of when in the author's life it was written, is more in line with the "secretary's" documentation. Still, as Holod and Halenko suggest, the successful dissemination of Taranowski's report shortly after it was written leaves no doubt that the text, as it now stands, may very well have been created for circulation. The printed version of Taranowski's narrative obviously had as its source his own ambassadorial report, the abbreviations having been made in order to appeal to a more general audience ${ }^{114}$.

Next, the scope: Taranowski goes on from his visit in Constantinople to witness an Ottoman military operation first hand, while Otwinowski provides more data on Ottoman social practices and curiosities. Taranowski presents more

\footnotetext{
109 KRASZEWSKI 1860, 10.

110 KRASZEWSKI 1860, 36.

111 DZIUBIŃSKI 1965, 240; for a discussion of the variant spellings of this toponym, see MATKOVIĆ 1891, 169, who derives it from a Bulgarian Obruštice. Obluciţa appears in a Turkish letter of 1512. Otwinowski, as other authors, uses the genitive plural (here required by the Polish preposition do). For a discussion with literature review, see BELDICEANU/BACQUÉGRAMMONT/CAZACU 1982, 60, n. 79.

112 KRASZEWSKI 1860, 10: “do Obkurzyc, mytnicy Turcy”; 36: "gdzie przewóz i myto jest".

113 HEYWOOD 1977, 40.

114 HOLOD/HALENKO 2014, 353
}

sweeping vistas, while Otwinowski is content to give daily post stages and the miles between them. Here, the impact of of the redacting process again comes to the fore: in Taranowski's case, the text appears to have been readied and adapted for dissemination shortly after the events described while Otwinowski may have returned to (or even composed) his text years or even decades later, relying on memory, a smattering of data from his reading and reports (perhaps even including Taranowski's) of other travelers.

Then, the impact of the two works, which could not have been more different. Otwinowski's report, whether we possess it in an original form compiled in the immediate aftermath of Bzicki's embassy (1557) or a version written (or, at least, redacted) later (perhaps, much later) in the author's life, appears to have languished, surviving in but a single manuscript. By contrast, Taranowski's report, to judge from the existing printed and manuscript copies, both in the original Polish, as well as in German, seems to have enjoyed fairly broad popularity. This, of course, was due to the interest accruing to Taranowski's spectacular data regarding the Turkish operations against Astrakhan.

This is underscored by the fact that the report was published, albeit in anonymous form, by Dietrich Gerlach (died 1575), who operated one of the most active publishing houses in sixteenth-century Nuremberg. Gerlach was one of a generation of publishers who printed popular works that appealed, and were affordable, to the non-scholarly, yet increasingly literate urban classes in the aftermath of the Protestant Reformation in Germany and was known for his publications of theological, juristic and travel literature ${ }^{115}$. Gerlach also specialized in the publication of popular works, whose ephemeral nature requires more a knack for business than a nose for literary merit. Why Gerlach chose to conceal the author's identity is unclear. Publishing of bootleg texts was, of course, quite common in the age before modern copyright laws and Taranowski, although a high official in Poland, was far away and thus unlikely to dispute Gerlach's publication. Perhaps the timeliness of the subject matter urged haste. Thus, the Nuremberg publisher may have seen anonymous publication as the most realistic approach to making the pamphlet available while it would still sell. Nevertheless, in Germany, Taranowski's work would prove ephemeral: except for the late eighteenth century bibliographic mention, it remained unknown until modern times.

In Poland, however, brief mentions of the journey appeared in such Polish works as the Latin Description of European Sarmatia by Alexander Guagnini (1578) ${ }^{116}$, in Macej Stryjkowski's Kronika (1582) ${ }^{117}$, and Bartosz Paprocki's heraldry compilation $(1584)^{118}$. As noted, a fairly complete retelling of Taranowski's narrative was inserted into the 115 FRANCK 1879; KRAUTWURST 1964.

116 Alessandro Guagnini, Sarmatiae Europeae descriptio, quae Regnum Poloniae, aniam, Samogitiam, Russiam, Masoviam, Prussiam, Pomeraniam... complectitur (Cracow: Matthias Wirzbista, 1578); see chapter "Tartarorum Campestrium, in Hordas divisorum, morumque \& consuetudinis vitae eorundem brevissima descriptio," fols. 4-5.

117 Kronika polska, litewska, zmödzka i wszystkiej Rusi Kijowskiej, Moskiewskiej... Macieja Stryjkowskiego (Królewiec: Jerzy Ostenberger, 1582), 775. Stryjkowski was personally acquainted with Taranowski, having accompanied him on the latter's last mission to Turkey in 1574-1575.

118 Herby rycerstwa polskiego przez Bartosza Paprockiego (1584), 977. 
fourth, posthumous edition of Marcin Bielski's Kronika $(1597)^{119}$. Marcin Paszkowski inserted this version into an expanded version of Guagnini's chronicle, which he published in his own Polish translation ${ }^{120}$. Subsequently, some form of the Polish version became known to, and was translated into Russian and copied by members of higher bureaucratic circles in the Muscovite state ${ }^{121}$. The fact that the Dobrogea itinerary, including detailed mention of the walls, was carried over Joachim Bielski into his father's Kronika, whence it was copied essentially verbatim by Paszkowski into his Polish translation of Guagnini, suggests that these authors considered the route followed by the ambassadors, together with their observations of defensive aspects, to be worth recording for the future.

Some further clues to thelegacy of both the Otwinowski and Taranowski texts could attach to the provenance of the Cracow manuscript edited by Kraszewski. The manuscript was in the possession of Count Henryk Iliński (1792-1871) at his ancestral seat at Romanów (today, Romaniv, Žytomir oblast, Ukraine). The Ilińskis were leading aristocrats of the Volhynia region of eastern Poland and, as such, held important military and political positions in the Polish Commonwealth. None appear to have been active in the diplomatic service or in foreign affairs, however, so a special interest in the subject matter covered by the materials in the manuscript is difficult to identify.

The position of the so-called Lelewel copy $(L)$ in the stema is also of interest. Dated to 1813 , the manuscript, named for Polish historian Joachim Lelewel (1786-1861), was first attested in the Muzeum Narodowy im. Swidzińskich in Sulgustów, later in the Krasiński Library (Signature 718) ${ }^{122}$. Born into a polonized Prussian noble family (Lölhöfel von Löwensprung) but living much of his life in exile, Lelewel was known for his meticulous research and minute attention to detail in his study of the sources. Konstanty Świdziński (17931855), a nobleman, and noted antiquarian and collector, befriended Lelewel in his early years and appears to have acquired a number of his manuscripts. The 1915 catalogue lists 10 positions, including Taranowski's travelogue, a convolute of correspondence, and other miscellaneous texts, including one of diplomatic relations with Russia and a history of Poland to Stefan Báthory's time. After his death, his collections, preserved in the Muzeum Narodowy im. Swidzińskich at Sulgustów, passed to the Krasiński Library ${ }^{123}$. The manuscript perished in 1944.

While it has been speculated that $L$ preserved a copy of $K^{124}$, this was not the opinion of Alexander Turyn, who, writing in 1929, was able to examine the original manuscript. Turyn states that Lelewel had transcribed the

\footnotetext{
119 Kronika Polska Marcina Bielskiego (Cracow: Jakub Sibeneycher, 1597; $\left.{ }^{2} 1764 ;{ }^{3} 1829\right), 626-38$.

120 Kronika Sarmacyey europskey, w którey się zamyka królestwo Polskie, ze wszystkiemi państwy, xięstwy, y prowincyami swemi; tudziez tez Wielkie Xięstwo Lithew., Ruskie, Zmudzkie, Inflantskie, Moskiewskie y częsc Tatarów (Cracow: Drukarnia Mikołaja Loba, 1611).

121 Known in seven late seventeenth-century manuscript compendia comprising the so-called "Kurbskii Collections" from apocryphal correspondence between Prince Kurbskii and Ivan IV (HOLOD/HALENKO 2014, 352).

122 PUŁASKI 1915, 751.

123 AJEWSKI 2004, 21-22.

124 TARDY/VÁSÁRY 1974, 218.
}

version in the 1597 edition of Bielski's Kronika $(B)^{125}$. Lelewel copied the manuscript in Warsaw in 1813, a time-frame for which a number of similar transcriptions of manuscripts and rare books (mostly pertaining to ancient geography for a book he would publish soon afterwards) are preserved in the Jagiellonian Library in Cracow $^{126}$. The manuscript containing $K$ was, at that time, in Romanów, making it impossible that Lelewel could have copied it in Warsaw. In an article dated to 1828, Lelewel mentions Taranowski's mission to "Tartary", citing as his source the 1764 edition of Bielski's Kronika, edited by the Polish Jesuit, Franciszek Bohomolec (17201784) ${ }^{127}$. This, therefore, is the most probable source for Lelewel's transcription of Bielski's text. As Bohomolec's 1764 text probably provides our best replacement for $L$, it is given together with Bielski's 1597 text above as the representatives of the $B$ branch. As compared to the 1597 text, Bohomolec's version does not include any variant readings that are of significance for the description of the walls.

Next, we must consider the value of the data provided by these two sources on the Dobrogea walls. Aside from confirming the presence of walls near the town of Alakap that were defensive in nature and about six (German) miles in length, the value of Otwinowski's contribution is limited by its conflation of the Dobrogea walls with the well-characterized Long Walls of Thrace. One learns more, perhaps, about the author and his interests than about the object he describes, as it shows him to be more learned and historically minded than Taranowski, interested in what he may have heard (or read) about a place he has visited. This conflation, as noted above, is possible evidence for the hyppthesis that the text of Otwinowski's report, at least as we possess it today, was composed or redacted years or even decades after the events described.

By contrast, Taranowski's description, especially the German version found in $W$ and $N$, provides interesting data on the walls' dimensions and state of preservation. While the measurements, both of thickness and length, can only be taken as rough estimates, they can be squared fairly well with historical, nineteenth-century reports and with geographical realities. Also of note is Taranowski's allusion to the "camp" (obóz), likely referring to one or more of the many forts and fortlets along the course of the Large Earthwork Wall and the Stone Wall that are particularly concentrated in the region of Alakap. This would seem to be the only premodern reference to the forts, which are such a prominent feature of the Dobrogea Walls.

It is also clear that Taranowski (and probably also Otwinowski) were aware of the general course of the walls beyond the local vicinity of Alakap. The area of Poarta Albă is unique in terms of the concentration of traces attributed to the Large Earthwork Wall and the Stone Wall; the Small Earthwork Wall (without forts) is not far distant to the south. Both authors are clear in their conception of the

\footnotetext{
125 TURYN 1929, 16.

126 Wisłocki 1881, 754-755.

127 Lelewel's contribution to the Annual of the Warsaw Royal Society of Friends of Science, dated by the editor of the 1863 Poznan edition of his collected works (T. XVIII/2, p. 366) to 1828: “Andrzeja Taranowskiego podróż $w$ głab Tartarii nietylko jest wspomniona u Paprockiego, ale opisana $w$ kronice polskiej Bielskiego w wydaniu Bohomolca t. I. od str. 570 do 579." The pagination confirms the reference to Taranowski's 1569 embassy.
} 
walls' purpose as a means of occluding access across the land between the Danube and Black Sea even though this becomes less apparent as the walls skirt the southern rim of the Karasu lakes in the more complex topography past Megidie. Certainly, neither Otwinowski nor Taranowski had the time nor inclination to trace the course of the walls to the Danube; hence, they must have received this information from an informant.

The spelling of place names is an often-exasperating problem in sources. Both Otwinowski and Taranowski use local toponyms that they would have learned from their guides or officials along the post road. Because neither man appears to have understood Turkish, they likely experienced difficulty differentiating among the different variants a name they heard from a variety of literate, semiliterate or illiterate informants. This situation is compounded by the effects of manuscript transmission, of which, especially for Otwinowski's text, we are poorly informed. For Taranowski's text, there is also the factor of transliteration between the Polish and German phonetical system. For the Nuremberg edition, the editor consistently applied the rules of German orthography, while the Vienna manuscript often corresponds more closely to Polish spelling, indicating that the manuscript is at least one step closer to Taranowski's lost original text. It is also more likely that the text reached Nuremberg by way of Vienna. At that time, the Polish and Austrian courts maintained good mutual relations that kept them informed of developments with common enemies. Thus, it would be likely that Taranowski's report made its way to Vienna, where it was immediately translated into German. As the focus of the present study is the value of these two documents as sources for the Dobrogea linear fortifications, the matter of spelling accuracy is secondary, there being no doubt regarding the identification of Alakap as the place at which Otwinowski and Taranowski encountered the Dobrogea walls.

Another question is that of the possible interdependence of the respective travelogues of Otwinowski and Taranowski. For several reasons discussed above, including the different social and diplomatic ranking of the respective authors, differences in focus and even in the structure of the reports, interdependence is not an immediately obvious issue. Also, because of their more prosaic nature within the setting of an exotic travelogue, "a typical itinerary, a set piece in envoys' reports" 128 , less attention has been paid to this passage, especially as it pertains to the geography of the Dobrogea. The general consensus on the chronology of the respective embassies would, at first glance, give priority to Otwinowski's report, suggesting that interdependence, if any, would favor Taranowski's use of Otwinowski as a source. If, however, as Otwinowski's biographers, Kot and Barycz, suggest, the report was written (or, at least, redacted) later in his life ${ }^{129}$, he may have consulted Taranowski's report (which seems to have enjoyed a wide circulation in both manuscript and printed form) as a means of refreshing his memory.

A review of the respective texts (taking into account

\footnotetext{
128 HOLOD/HALENKO 2014, 354.

129 KOT 1934, 4; BARYCZ 1979, 641-645. KOT suggests that the report may have, at least, been edited after 1596
}

the entirety of the route at least from the Danube to Constantinople) reveals similarities and contrasts. In the passages at hand, both authors mention walls at Alakap that have been built by the Greeks to defend against "the heathen" or specific tribes, e.g. the Bulgarians and Tatars. Both allude to the walls' stretching between distinct bodies of water (Danube-Black Sea vs. Black Sea-White Sea) and both also give the walls a length in miles, of which it would appear that Otwinowski's six (German) miles correlate well with Taranowski's 30 (Roman) miles. Taranowski provides additional details on the walls, which Otwinowski could have excerpted, while at the same time contaminating the passage by conflating the Dobrogea walls with the Thracian Long Walls of Anastasius. In a subsequent passage, both authors provide details about the Bulgarian town, Ajtos, which are strikingly similar in content, order of facts and formulation, once again with a slight advantage to Taranowski in terms of quantity of data presented ${ }^{130}$. Here, too, Otwinowski's conflation of the Dobrogea and Thracian walls could support the notion that he wrote (or augmented) his report (as currently preserved) later in life. A possible source of information on Anastasius and the Thracian Long Walls is Bielski's Kronika, the first edition of which appeared in 1551. If, however, following Kot, we allow for a very late composition or redaction of Otwinowski's report (after 1596), he may have derived at least some of his data from the postumous fourth edition of Bielski's Kronika, which reproduces almost verbatim the passage describing Taranowski's route through the Dobrogea, Bulgaria and Thrace.

The travelogues of the sixteenth-century Polish diplomats Erazm Otwinowski and Andrzej Taranowski are important, but as yet overlooked, sources on the Dobrogea walls as well as on local geography and toponymy. They represent the earliest Western sources for the Dobrogea walls and contain the first pre-modern mention of the forts which are an important feature of these defensive structures. These mentions have not yet been included in the discussion of the history of the Dobrogea walls. They will add to our understanding of their history and state of preservation in a period for which we are not otherwise well informed. 


\section{REFERENCES}

AJEWSKI 2004

Ajewski, K., Kolekcjonerstwo Konstantego Świdzińskiego. Z dziejów Biblioteki Ordynacji Krasińskich, Rocznik Biblioteki Narodowej 36, 21-78.

ANETSHOFER 2012

Anetshofer, H., Legends of Sarı Saltık in the Seyahatnâne and the Bektaski Oral Tradition. In: Tezcan N., Tezcan S., Dankoff R. (eds.), Evliyâ Çelebi: Studies and Essays Commemorating the 400th Anniversary of his Birth (Istanbul: Ministry of Culture and Tourism), 296-304.

BACCI/ROHDE 2014

Bacci, M., Rohde, M., The Holy Portolano: The Sacred Geography of Navigation in the Middle Ages: Fribourg Colloquium 2013 (Berlin: Walter de Gruyter).

BARTOSZEWICZ 1860

Bartoszewicz, J., Pogląd na stosunki polski z Turcyą I Tatarami (Warszawa: A. Nowolecki).

BARYCZ 1979

Barycz, H., Otwinowski, Erazm. In: Polski słownik biograficzny (Wrocław: Ossolineum), 24, 641-645.

BELDICEANU/BACQUÉ-GRAMMONT/CAZACU 1982

Beldiceanu, N., Bacqué-Grammont, J.-L., Cazacu, M., Recherches sur les Ottomans et la Moldavie pontodanubienne entre 1484 et 1520, Bulletin of the School of Oriental and African Studies 45/1, 48-66.

BELDICEANU/BELDICEANU-STEINHERR 1975

Beldiceanu, N., Beldiceanu-Steinherr, I., Déportation et pêche à Kilia entre 1484 et 1508, Bulletin of the School of Oriental and African Studies 38/1, 40-54.

BERINDEI/VEINSTEIN 1981

Berindei, M., Veinstein, G., Réglements fiscaux et fiscalité de la province de Bender-Aqkerman 1570, Cahiers du monde russe et soviétique 22/2-3, 251-328.

BIELSKI 1856

Bielski, M., Kronika Marcina Bielskiego (Ks. 4-5), wyd. K. J. Turowksiego (Sanok: K. Pollak).

CROITORU 2007

Croitoru, C., Fortificaţii liniare romane în stânga Dunării de jos (II): Terminologie relativă (Brăila: Istros).

DZIUBIŃSKI 1965

Dziubiński, A., Drogi handlowe polsko-tureckie w XVI stuleciu, Przeglad Historyczny 56/2, 232-259.

DZIUBIŃSKI 1996

Dziubiński, A., Polsko-litewskie napady na tureckie pogranicze czarnomorskie w epoce dwu ostatnich Jagiellonów, Kwartalnik Historyczny 103/3, 53-87

ESTREICHER 1894

Estreicher, K. J., Bibliografia Polska, T. XIII (Ser. III, T. 2; Kraków: Polska Akademia Umiętności)

ESTREICHER 1936

Estreicher, S., Bibliografia Polska, T. XXXI (Ser. III, T. 20; Kraków: Polska Akademia Umiętności).

EVLIYÂ ÇELEBI 1984

Evliyâ Çelebi, Seyahatnâme, III: Rumeli-Solkol ve Edirne, ed. İ. Parmaksizoğlu (Ankara: Kültür ve Turizm Bakanlığ yayıları).

FAROQHI 1982

Faroqhi, S., Camels, Wagons, and the Ottoman State in the Sixteenth and Seventeenth Centuries, International Journal of Middle East Studies 14/4, 523-539.

FRANCK 1879

Franck, J., Gerlach, Dietrich. In: Allgemeine Deutsche Biographie 9, 8-9.

GEMIL 2009

Gemil, T., Romanians and Ottomans in the XIVth-XVIth
Centuries (Bucureşti: Editura Enciclopedică).

GRÓDZ 2015

Gródz, S., Sixteenth-Century Anti-Turkish Literature in Poland and Lithuania. In: Thomas D., Chesworth J. (eds.), Christian-Muslim Relations: A Bibliographical History, v. 7: Central and Eastern Europe, Asia, Africa and South America (1500-1600) (Leiden-Boston: E. J. Brill), 443-455.

\section{HASLUCK 1912}

Hasluck, F. W., Studies in Turkish History and Folk-Legend, The Annual of the British School at Athens 19, 198-220.

\section{HEYWOOD 1977}

Heywood, C. J. Some Turkish Archival Sources for the History of the Menzilhane Network in Rumeli during the Eighteenth Century (Notes and Documents on the Ottoman Ulak, I), Boğaziçi Üniversitesi Dergisi, 4-5, 39-55.

\section{HOLOD/HALENKO 2014}

Holod, R., Halenko, O., The Harsh Landscapes of "Mother Sarmatia": Steppe Ukraine through the Eyes of a SixteenthCentury Polish Diplomat, Harvard Ukrainian Studies 32/33, 349-376 (Part 1: ЖНИВА: Essays Presented in Honor of George G. Grabowicz on His Seventieth Birthday).

\section{HÓVÁRI 1984}

Hóvári, J., Customs Register of Tulça (Tulcea), 1515-1517, Acta Orientalia Academiae Scientiarum Hungaricae, 38/1-2, 115-141.

\section{INWENTARZ 1938}

Inwentarz rękopisow Biblioteki Jagiellońskiej Nr. 4175-6000 (Kraków: Nakł. Biblioteki Jagiellońskiej).

\section{JABLONOWSKI 1937}

Jablonowski, H., Die Aussenpolitik Stephan Báthorys, Jahrbücher für Geschichte Osteuropas 2/1, 11-80.

\section{JACOBY 1965}

Jacoby, G., The Mile Used by Lucas Waghenaer in 1583, Imago Mundi 19, 116.

\section{JANICKI 1879}

Janicki, I., Perska księga na polskijęzyk przełożona (Warszawa: Druk. Ziemkiewicza i Noakowskiego).

\section{KOŁODZIEJCZYK 2011}

Kołodziejczyk C., The Crimean Khanate and Poland-Lithuania: International Diplomacy on the European Periphery (15th-18th Century). A Study of Peace Treaties Followed by Annotated Documents (Leiden: E. J. Brill)

\section{KOT 1934}

Kot, S., Erazm Otwinowski. Poeta-dworzanin i pisarz różnowierczy, Reformacja w Polsce 6 (21-24), 1-37.

\section{KRASZEWSKI 1860}

Kraszewski, I. J., Podróze i poselstwa Polskie do Turcyi a mianowicie: Podróz E. Otwinowskiego 1557, Jędrzeja Taranowskiego komornika j. k. m. 1569, i Poselstwo Piotra Zborowskiego 1568 przygotowane do druku z rękopismu przez J. I. Kraszewskiego, wyd. Kazimierza Jozefa Turowskiego (Kraków: Wyd. Biblioteky Polskiej).

\section{KRAUTWURST 1964}

Krautwurst, F., Gerlach, Dietrich. In: Neue Deutsche Biographie, 6, 300-301.

\section{KURAT 1966}

Kurat, A. N., Türkiye ve İdil boyu: 1569 Astarhan seferi, Tenİdil kanali ve XVI-XVII yüzyil Osmanli-Rus münasebetleri (Ankara: Ankara Üniversitesi Basımevi).

\section{LELEWEL 1863}

Lelewel, J., Historia polska do końca panowania Stefana Batorego, wyd. E. Ryjaczewskiego (Poznań: Nakł. J. P. Żupańskiego).

LINDE 1808

Linde, S. B., Słownik języka polskiego (Warszawa: Druk autora), T. II. 


\section{MASON/CROITORU 2016}

Mason, R., Croitoru, C., Carl Schuchhardt's Contributions on Ancient Linear Fortifications along the Lower Danube [Ad Limites Orbis Romani, IV](Cluj-Napoca: Mega).

MATKOVIĆ 1891

Matković, P., Putovanja po Balkanskom poluotoku XVI. vieka. XI. Dva putopisa poljskih poslanstva u Carigrad: E. Otvinovskoga od god. 1557 i Andrije Taranovskoga, komornika, od god. 1569, Rad Jugoslavenske akademije znanosti i umjetnosti 105, 142-201

MAYENOWA 1975

Mayenowa, R. N., Słownik Polszczyzny XVI wieku (WrocławWarszawa: Ossolineum), T. IX.

MAYENOWA 1990

Mayenowa, R. N., Słownik Polszczyzny XVI wieku (WrocławWarszawa: Ossolineum), T. XIX.

MAYENOWA 1998

Mayenowa, R. N., Słownik Polszczyzny XVI wieku (Warszawa: Instytut Badań Literackich PAN), T. XXVI.

MILLER 1916

Miller, K., Itineraria Romana: Römische Reisewege an der Hand der Tabula Peutingeriana dargestellt (Stuttgart: Strecker und Schröder).

MINKOVA 2014

Minkova, K. V., Mezhdunarodnaya torgovlya na territorii Moldavii v XIV-XVI vv. Politicheskie aspekty, Rusin 2 (36), 201-216.

NIESKIECKI 1743

Niesiecki, F., Korona polska przy Złotej Wolności (Lwów: Drukarnia kollegium Societatis Iesu)

NIESKIECKI 1842

Niesiecki, F., Herbarz polski Kaspra Niesieckiego S.J. oprac. N. M. Bobrowicza, T. IX (Lipsk: Breitkopf und Härtel).

NOSOWSKI 1974

Nosowski, J., Polska literatura polemiczno-antyislamistyczna XVI, XVII i XVIII w., (Warszawa: Akademia Teologii Katolickiej), T. 1.

PANAITESCU 1930

Panaitescu, P. P., Călătorii poloni in Ţările Române, București: Cultura Națională, 1930.

PANAITESCU 1933

Panaitescu, P. P., La route commerciale de Pologne à la Mer Noire au Moyen Âge, Revista Istorică Română 3/2-3, 172 193.

POCIECHA 1937

Pociecha, W., Bzicki Andrzej. In: Polski słownik biograficzny (Kraków, Gebethner i Wolff), 3, 185-186.

\section{POLLAK 1966}

Pollak, R., Antologia pamiętników polskich XVI wieku (Wrocław-Warszawa-Kraków: Wyd. PWN).

PREJS 1999

Prejs, M., Egzotyzm w literaturze staropolskiej. Wybrane problemy (Warszawa: Instytut Literatury Polskie).

PUŁASKI 1907

Pułaski, F., Źródła do poselstwa Jana Gnińskiego wojewoda chetminskiego do Turcyi $w$ latach 1677-1678 (Warszawa: Druk. Rubiszewskiego i Wrotnowskiego).

PUŁASKI 1915

Pułaski, F., Opis 815 rękopisów Biblioteki Ordynacji Krasińskich (Warszawa: Nakł. Funduszu Świdzińskich).

SCHUCHHARDT 1918

Schuchhardt, C., Die sogenannten Trajanswälle in der Dobrudscha, Abhandlungen der Preussischen Akademie der Wissenschaften (Philosophisch-historische klasse), 12 (new edition with commentary in MASON/CROITORU 2016, 239-330).

\section{SPULER 1936}

Spuler, B., Europäische Diplomaten in Konstantinopel bis zum Frieden von Belgrad (1739), Jahrbücher für Geschichte Osteuropas, 1/3, 383-440.

STAMM 1938

Stamm, E., Staropolskie miary. Część I: Miary długości i powierzchni (Warszawa: Główny urząd miar).

TARDY/VÁSÁRY 1974

Tardy, L., Vásáry, I., Andrzej Taranowskis Bericht über seine Gesandtschaft in der Tartarei (1569), Acta Orientalia Academiae Scientiarum Hungaricae, 28/2, 213-252.

TURYN 1929

Turyn, A., De Aelii Aristidis codice varsoviensi atque de Andrea Taranowski et Theodosio Zygomala (Cracoviae: Academia Polona Litterarum; Archiwum Filologiczne Nr. 9).

WHITBY 1985

Whitby, M., The Long Walls of Constantinople, Byzantion $55 / 2,560-583$

WILCZEK 1994

Wilczek, P., Erazm Otwinowski: Pisarz ariański (Katowice: Gnome Books).

WILCZEK 2016

Wilczek, P., Polonia Reformata: Essays on the Polish Reformation(s) (Göttingen: Vandenhoeck \& Ruprecht).

WISŁOCKI 1881

Wisłocki, W., Katalog rękopisów Biblijoteki Uniwersytetu Jagiellońskiego (Kraków: Drukarnia Uniwersytetu Jagiellońskiego), T. II.

YERASIMOS 1991

Yerasimos, S., Les voyageurs dans l'Empire Ottoman, XIVeXVI siècles: bibliografie, itinéraires et inventaire des lieux habités (Ankara: Société turque d'histoire).

ZARĘBSKI 2015

Zarębski, R., Bliski wschód w XVI-wiecznych pamiętnikach polskich (na przykładzie wybranych kręgów tematycznych), Przegląd Orientalistyczny, 3-4, 179-190. 


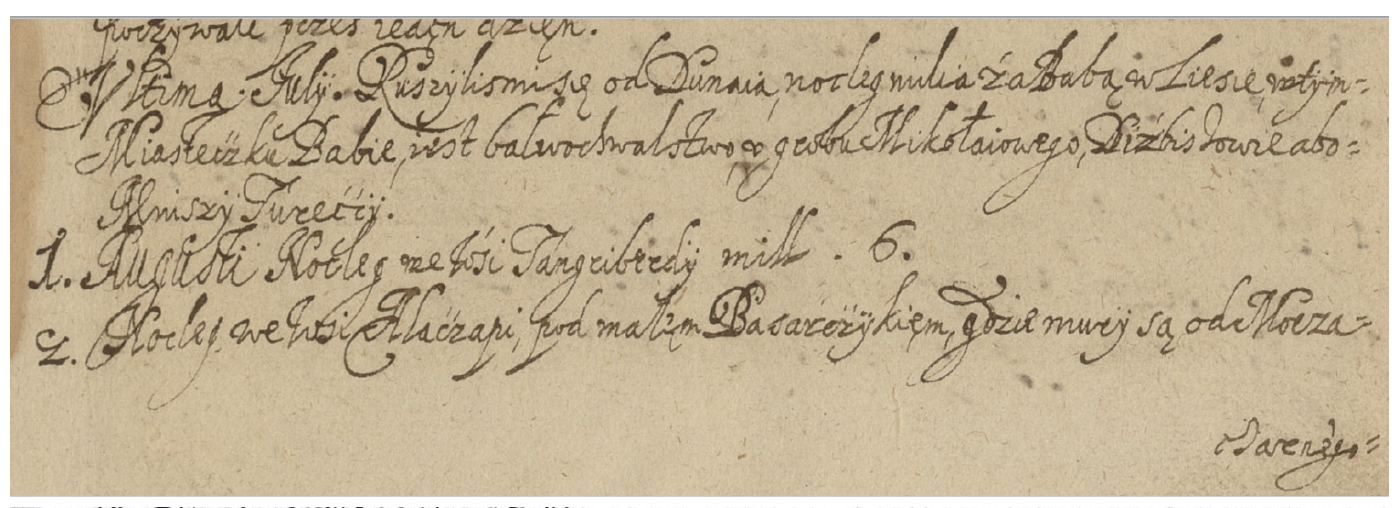

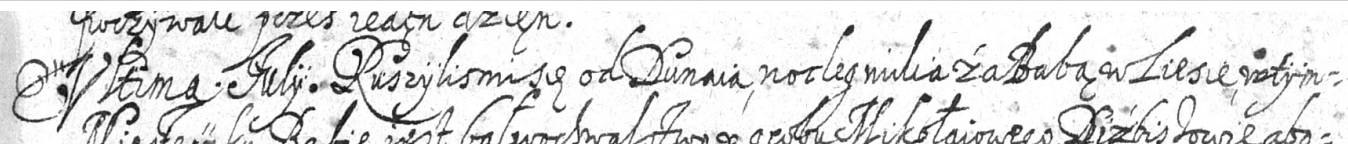

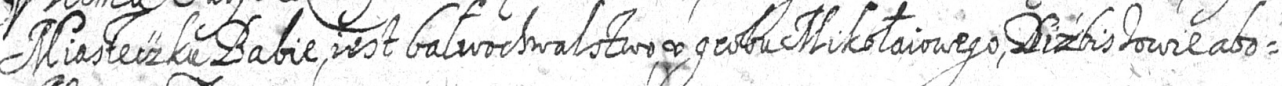

- Ilnisyourcizy.

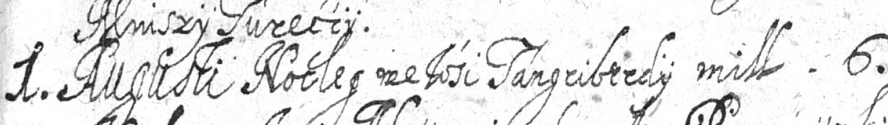

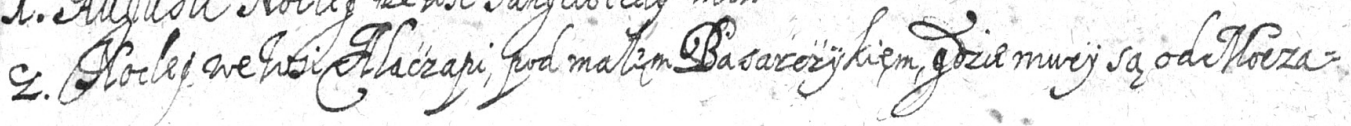

$$
\text { Darenis = }
$$

Fig. 1. Erazm Otwinowski, Wypisanie drogi tureckiej (Biblioteka Jagiellońska w Krakowie, MS. 5267, fo. 119).

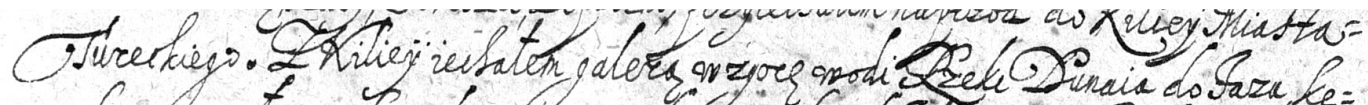

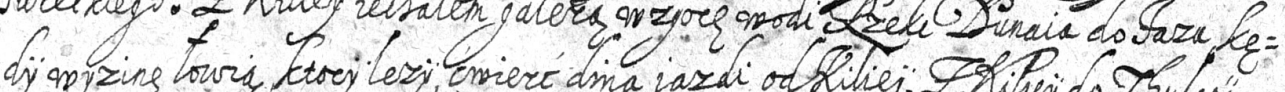
Il Therido Sulcre=

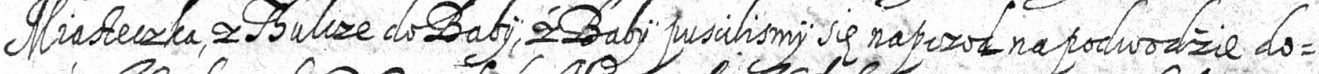

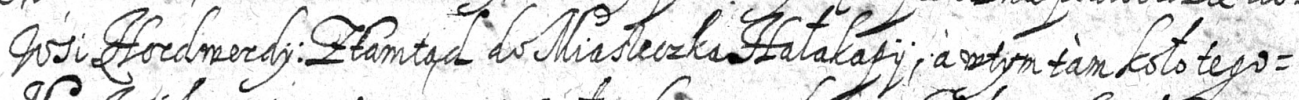

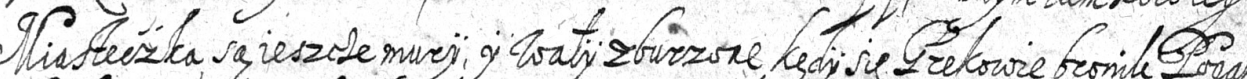

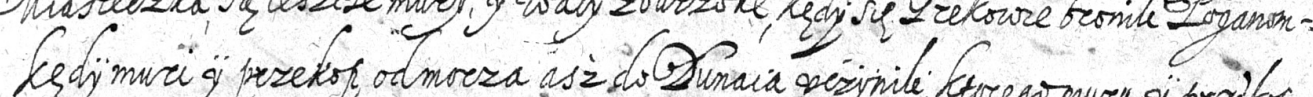

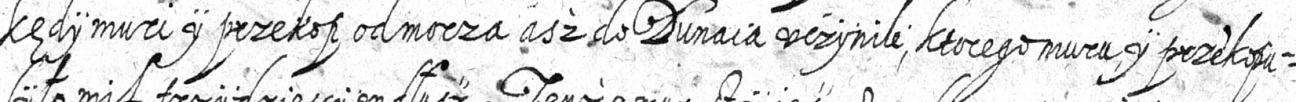

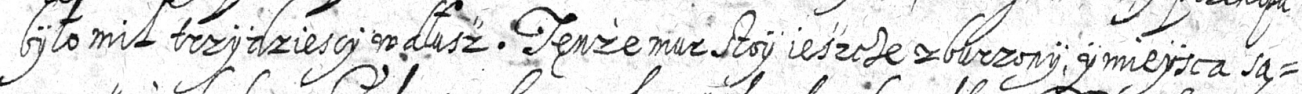

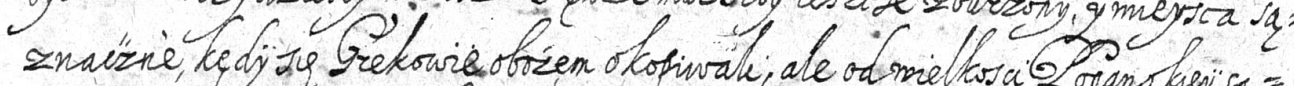

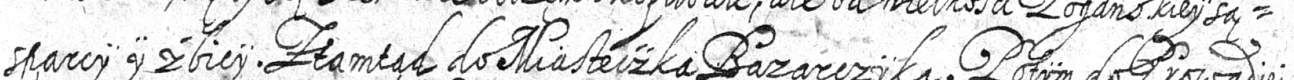

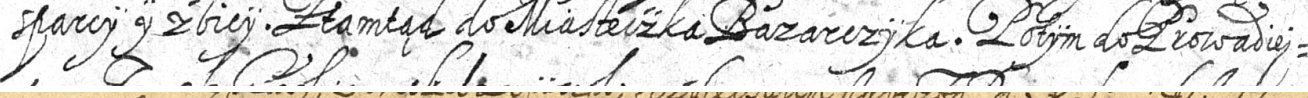
OA

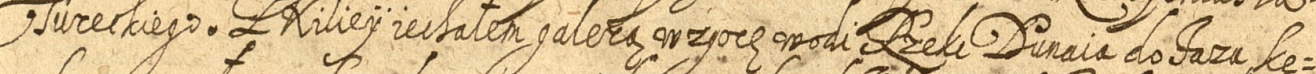

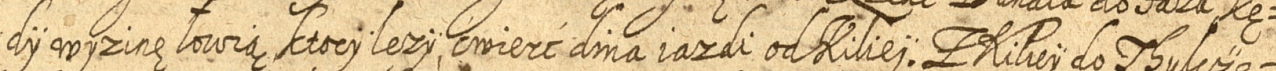
10 $1 \%$ ore

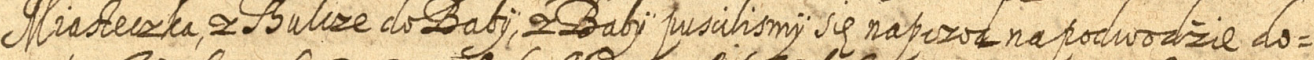

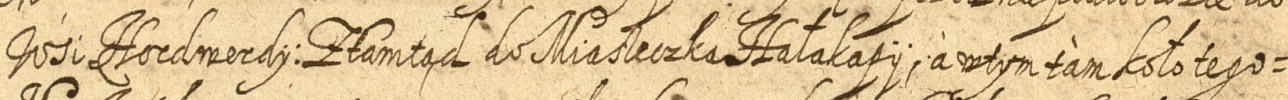

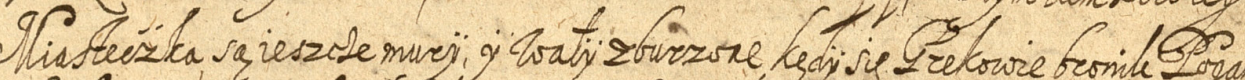

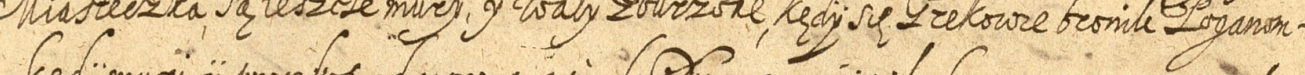

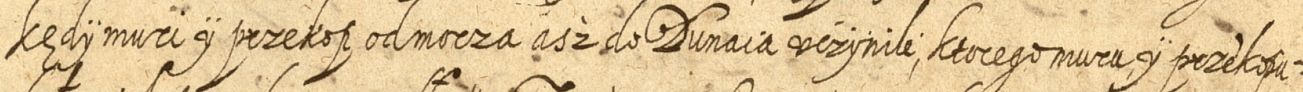

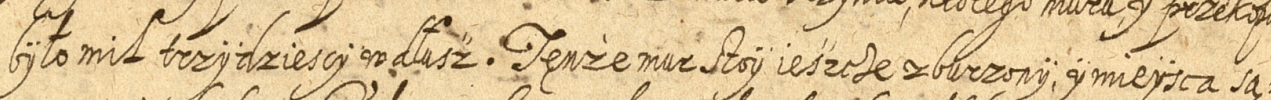

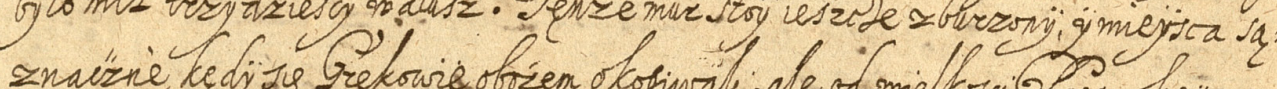

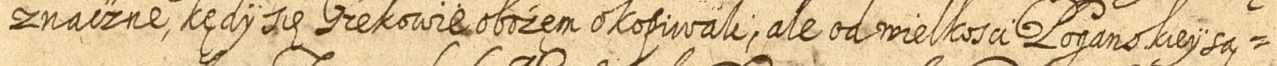

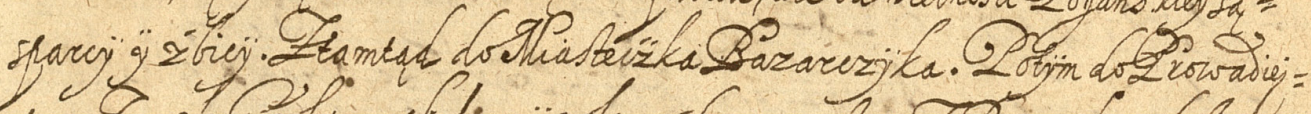

Fig. 2. Andrzej Taranowski, Krótkie wypisanie drogi z Polski do Konstantynopola (Biblioteka Jagiellońska w Krakowie, MS. 5267, fo. 211) 


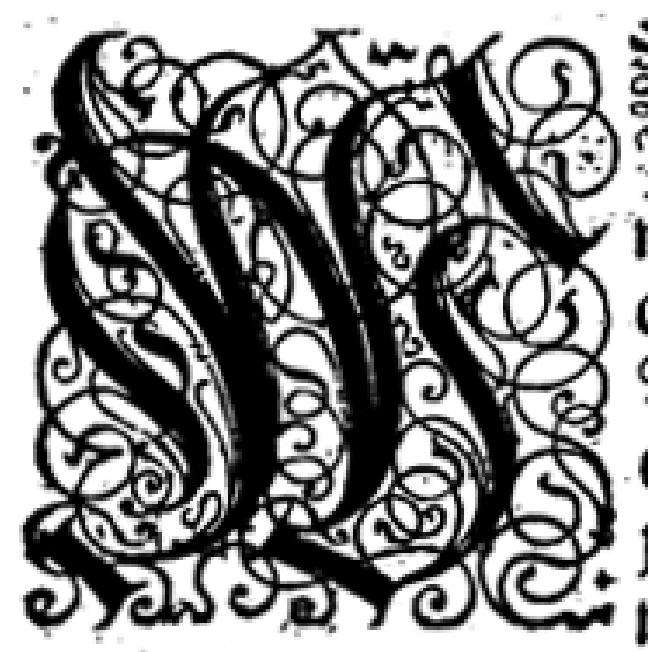

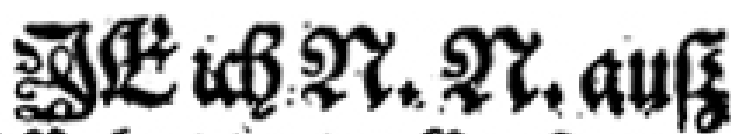
Poiten gegen Sonfantio nopel / ourch bic $2 B a l a$. dien/Durdo ben bef fatenen Faalo Bufotwis / in twet? dem fưt 73. Dasift I im 497. Sat/50000. 9ore nifder Ssiann von $23 a l a$. doen auffecinen tagerlegt pein/auth auff Edate

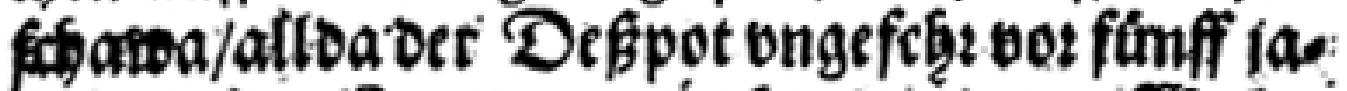

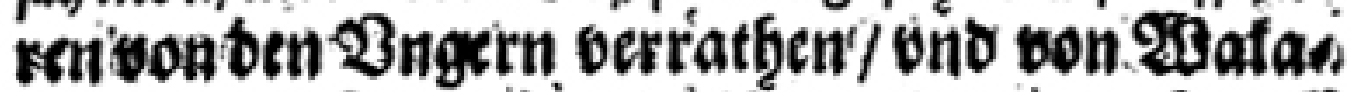

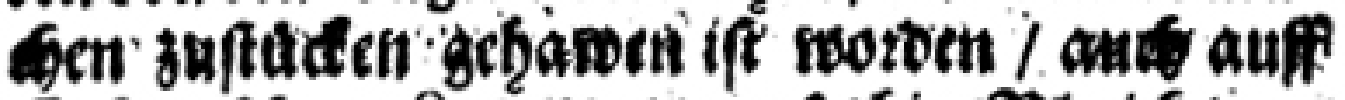

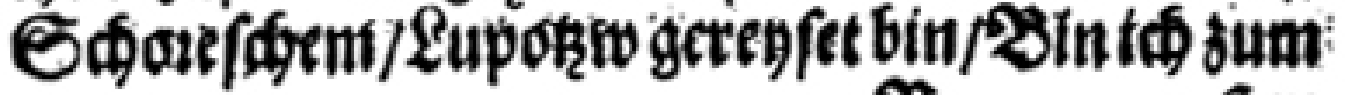
$\mathfrak{B}$

erfiten

erfteninn ein Târdif

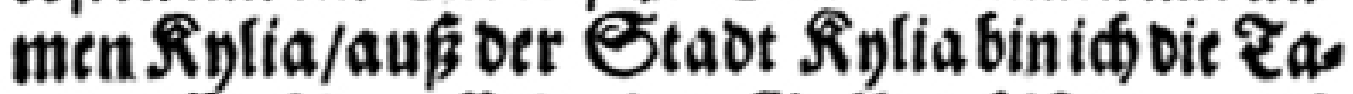

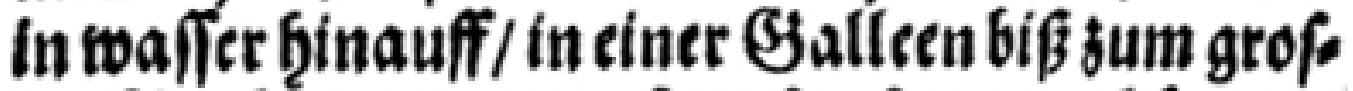

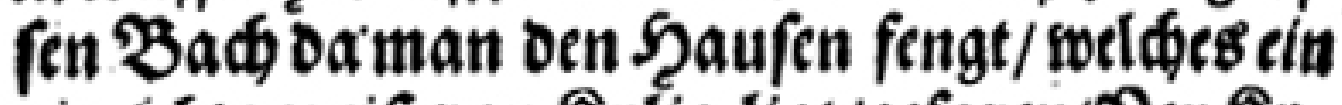

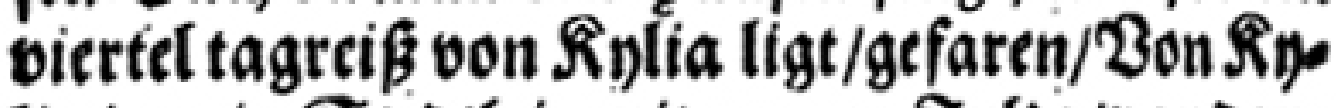
lia inn ein Steottein mit namen Eulfa/bond Dans nen inn ein Stadt $\mathfrak{B a b i} /$ /eeind rwir die Poft getito ten in ein SGriedif

Bon Dannen in ein Stedtein Şalafapi/ben Dem ferben Stedtein feino nod) alte mauren uno

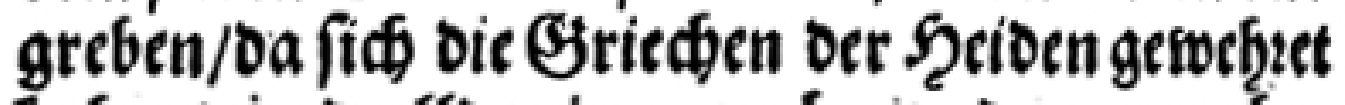
Waben/vinno alldacinen graben vnd mauren bet)

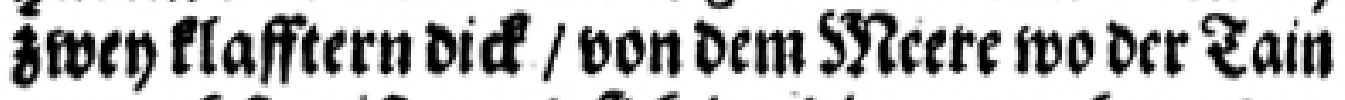
am necd/fen itt/onnd fid inn Die zo. mentswegs ero frtedt/gemadft / / wie deñ foldgs auff den beeutigen tagnodis buferten. 


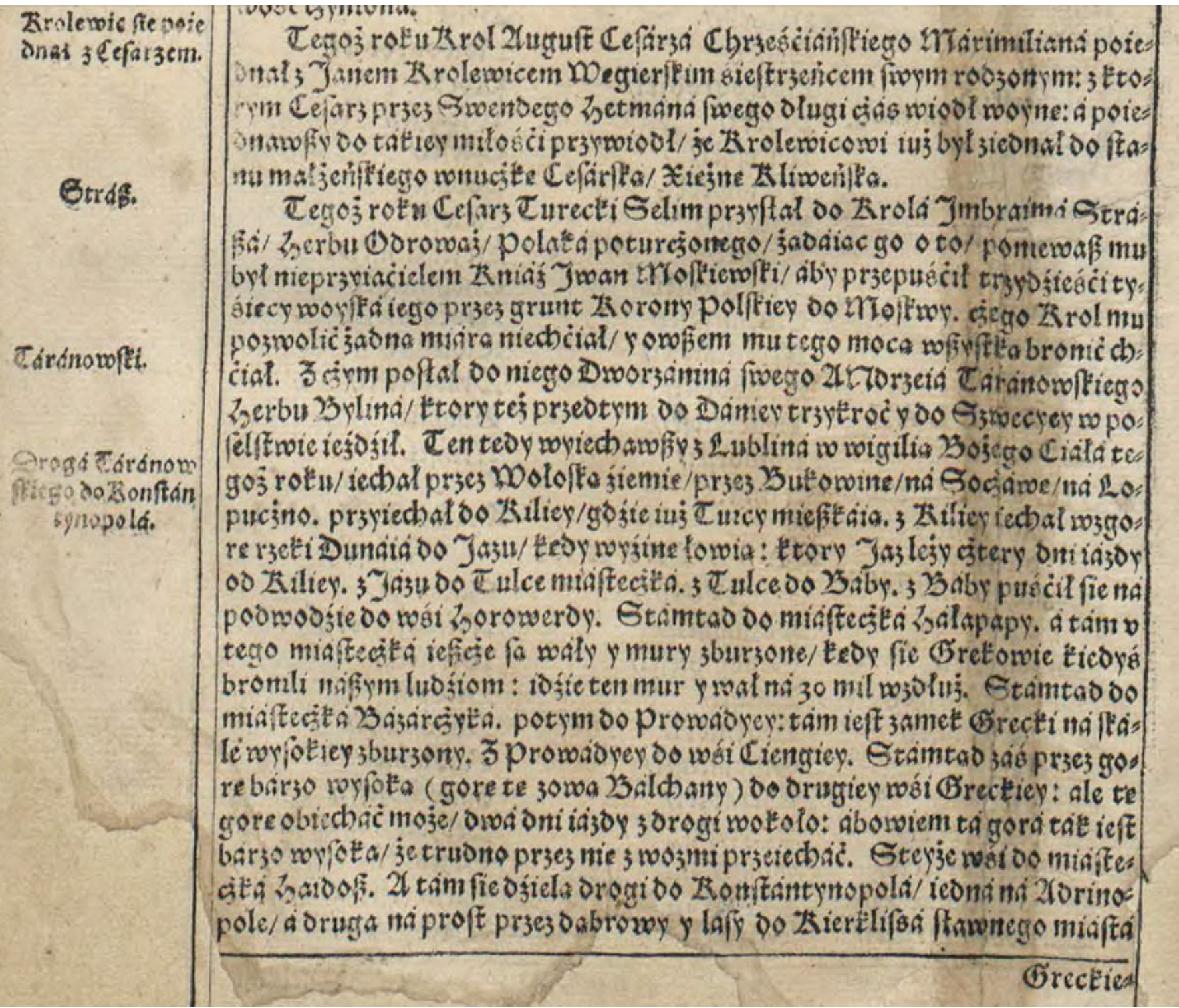

Fig. 4. Marcin Bielski, Kronika Polska, ed. Joachim Bielski, Cracow, Jakob Siebeneycher, 1597, Page 626 (Biblioteka Jagiellońska w Krakowie, sign. BJ St. Dr. Cim. 8176). 


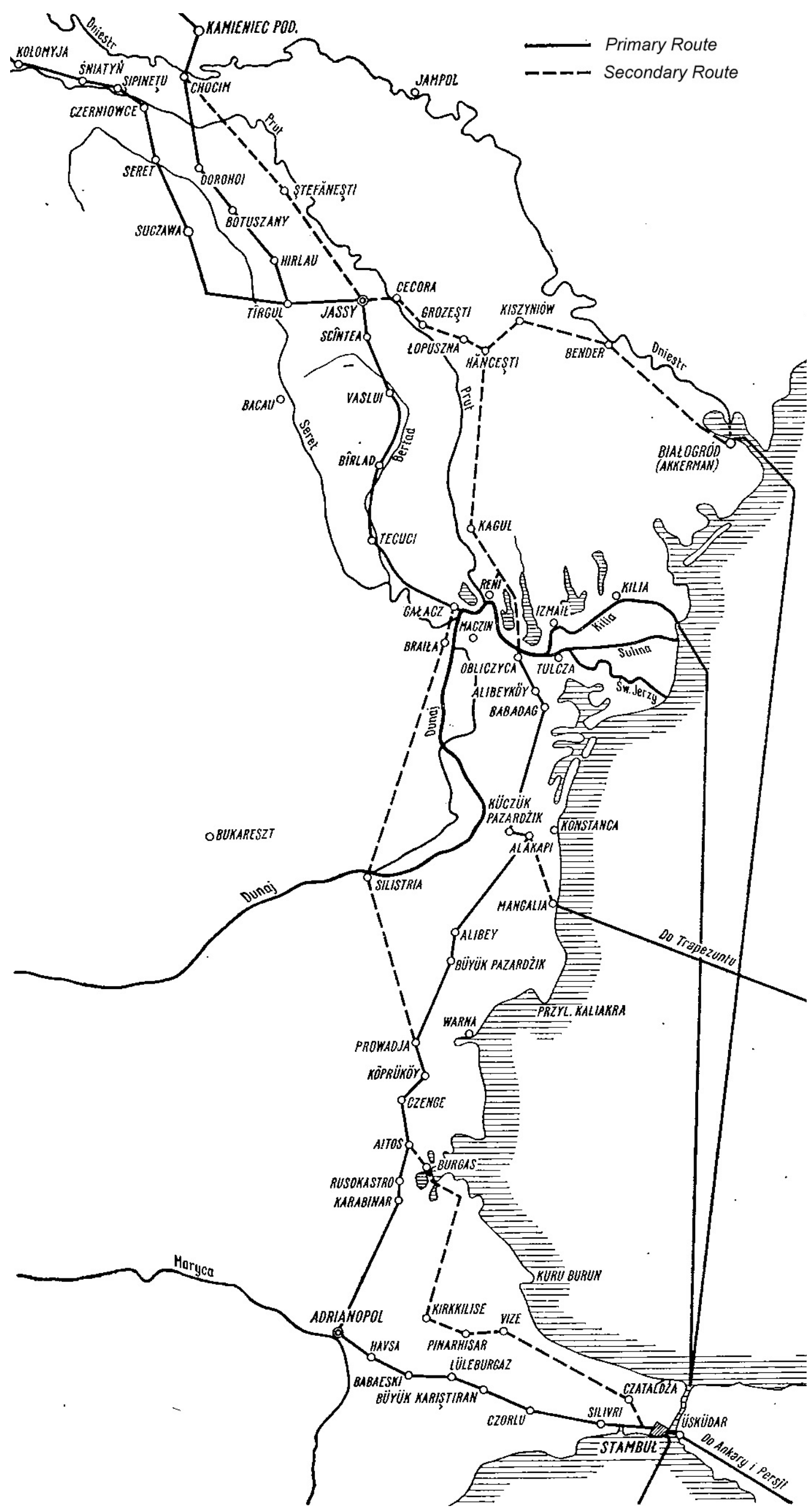

Fig. 5. Polish routes to Constantinople (adapted from DZIUBIŃSKI 1965). 

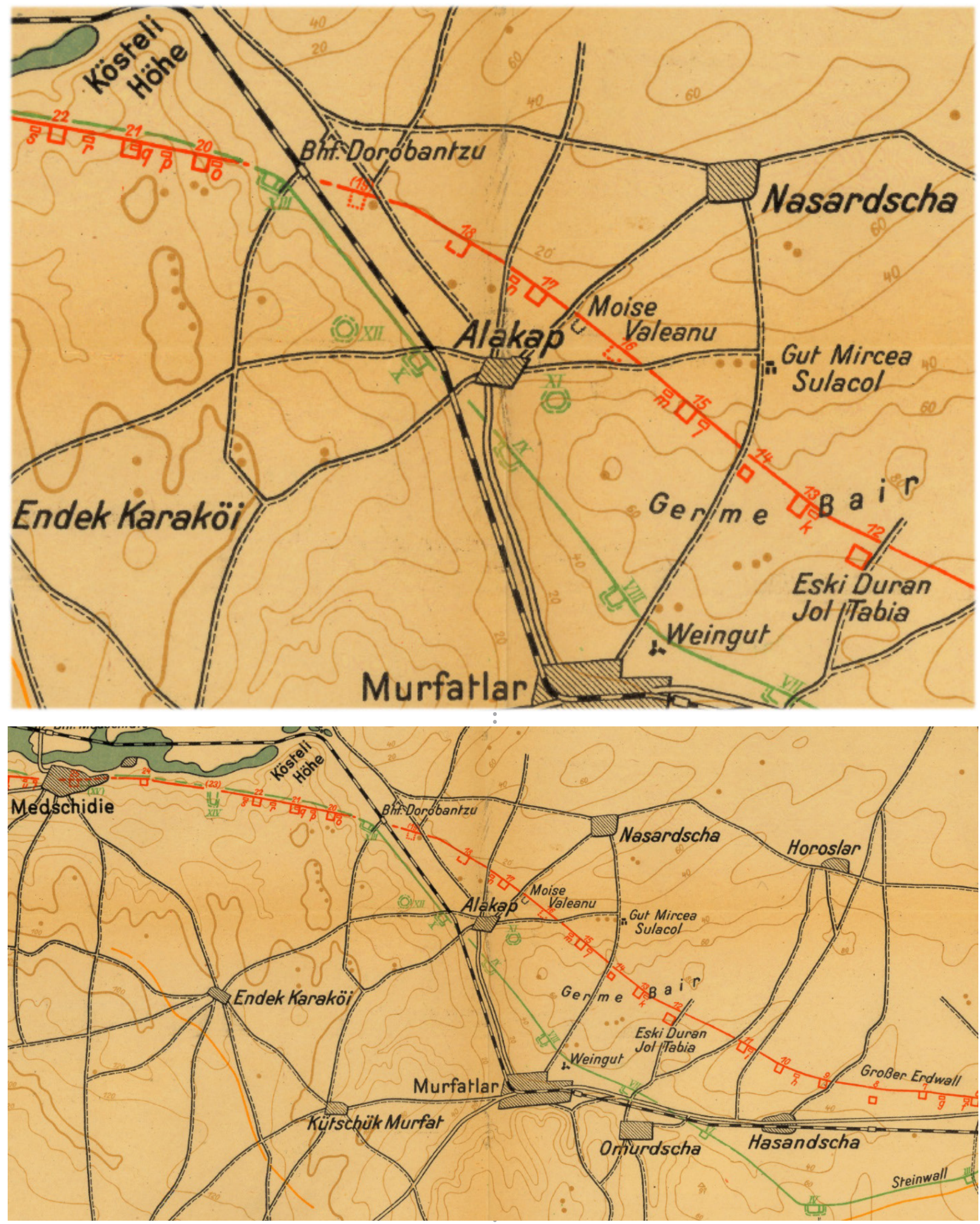

Fig. 6. Dobrogea Walls in the Alakap-Murfatlar region as documented by S̊CHUCHHARDT 1918. 